Uluçay, M. (2021). Okul öncesi çocuklarının kelime hazinesi ile derlem temelli sıklık listelerinin karşılaştırılması. Ana Dili Eğitimi Dergisi, 9(4), 1443-1468.

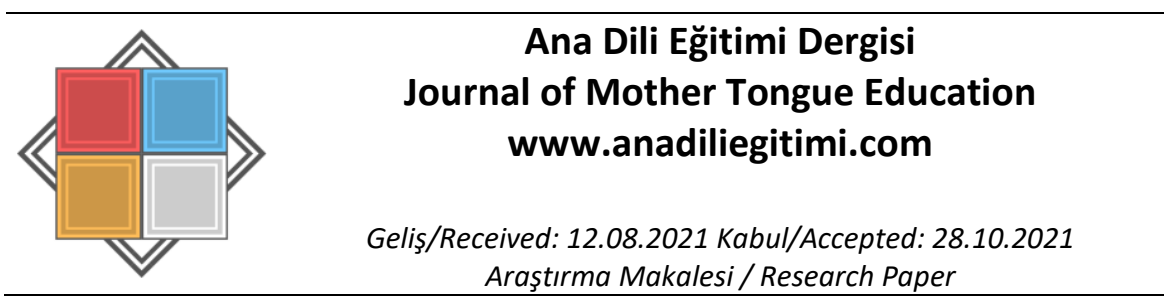

\title{
Okul Öncesi Çocuklarının Kelime Hazinesi ile Derlem Temelli Sıklık Listelerinin Karşılaştırılması
}

\author{
Melike ULUÇAY*
}

Öz

Bu çalışma 60 ay ve üzeri okul öncesi çocuklarının en sık kullandıkları ilk 1000 kelime ile derlem temelli çeşitli listeleri karşılaştırarak, okul öncesi çocuklarıın dil edinim sürecinde kullandıkları kelimelerin bu listelerden ne ölçüde farkılış̧ı̆̆ııı ortaya koymak amacıyla yapılmıştır. Çocukların kelime hazinesini tespit etmek için sekiz hafta süreyle etkileşimli okuma yöntemiyle kitap okunmuş, çocuklar konuşturularak söyledikleri her söz kayıt altına alınmış ve kelime havuzu oluşturulmuş böylece sıklık listesi elde edilmiştir. Bütüncül çoklu durum deseni kullanılan çalışmada okul öncesi çocuklarının kelime sıklık listesi ile genel bir derlem olan A Frequency Dictionary of Turkish'in, Hedef Kelime Listesi'nin, çocuk kitaplarının, 1. Sınıf Türkçe ders kitabının ve ilkokul öğrencilerinin ilk 1000 kelimesi karşılaştırılmışır. Araştırmanın sonucunda okul öncesi çocuklarının ilk 1000 kelimesi ile A Frequency Dictionary of Turkish'in ilk 1000 kelimesi ve 1. Sınıf Türkçe Kitabının ilk 1000 kelimesi arasında farklılaşma oranının daha fazla; Hedef Kelime Listesi, çocuk kitapları ve ilkokul öğrencilerinin ilk 1000 kelimesi arasında farklılaşma oranının daha az olduğu tespit edilmiştir.

Anahtar Kelimeler: Okul öncesi, kelime hazinesi, kelime sıklığı

\section{A Comparison of Preschool Children's Vocabulary and Corpus-Based Frequency Lists Abstract}

The aim of this study, comparing 60 months and older pre-schoolers' first most frequently used 1000 words with various corpus-based lists, is to reveal the extent to which the words used by preschool children in the language acquisition process differ from these lists. To determine the vocabulary levels of the children, interactive reading method was applied for eight weeks, any vocabulary produced by the children was recorded, a word pool was created, and thus a frequency list was obtained. In the study in which a holistic multi-case design was used, the frequency list of preschool children and the first 1000 words of A Frequency Dictionary of Turkish, which is a general corpus, the first 1000 words of Target Word List, the first 1000 words of a children's book, the first 1000 words of $1^{\text {st }}$ grade Turkish textbooks, and the first 1000 words of primary school students were compared. As a result, the rate of differentiation between the first 1000 words of preschool children and the first 1000 words of the A Frequency Dictionary of Turkish, and the first 1000 words of the $1^{\text {st }}$ Grade Turkish Book was found to be quite high while it was seen that there was less differentiation between the Target Word List, children's books, and the first 1000 words of primary school students.

Keywords: Preschool, vocabulary, word frequency

\section{Giriş}

Anne karnındayken sesleri duymaya başlayan, dünyaya geldiğinde ağlayarak iletişim kuran bir bebek 1 yaşından itibaren üretici kelime hazinesindeki sınırlı sayıda olan ilk kelimelerini kullanarak o zamana kadar sadece kapısından bakabildiği dilin dünyasına adım atar. Çocuk önce ihtiyaçlarını ifade

\footnotetext{
${ }^{*}$ Dr. Öğr. Üyesi, Erzincan Binali Yıldırım Üniversitesi, Eğitim Fakültesi, Temel Eğitim Bölümü, Erzincan, melikeulucay@gmail.com, ORCID:orcid.org/0000-0001-6333-1286
} 
etmek için dili bir araç olarak kullanırken devam eden süreçte dünyayı anlamak, her yönüyle kendini ifade etmek, sosyalleşmek ve içinde yaşadığı toplumda kendine bir yer edinebilmek için dili bir araç olarak kullanmaya devam eder.

Dil; seslerin birleşmesiyle heceler, hecelerin birleşmesiyle kelimeler, kelimelerin birleşmesiyle kelime grupları ve cümlelerin oluştuğu çok düzenli ve sistemli bir yapıdır. Bu sistemli düzen insanoğlunun dil öğrenme sürecinde de kendini gösterir. Bebekler öncelikle ses çıkarırlar; ardından heceler, hecelerden sonra kelimeler ifade eder ve 18. aydan itibaren cümle kurmaya başlarlar. Bu sıralı düzen hiçbir bebek ve çocukta değişmez ancak çeşitli faktörlerin etkisiyle daha hızlı ya da daha yavaş devam edebilir. Hayat boyu devam eden dil gelişiminin en kritik dönemi okul öncesi dönemde, her çocuğun dil gelişiminin -çeşitli faktörlerden etkilendiği için- farklılıklar gösterebildiğini belirten birçok çalışma yapılmıştır (Dereli ve Koçak, 2005; Erdoğan, Bekir ve Aras, 2005; Ergin, 2012; Eryılmaz, Uladı, Geyik ve Öztürk, 2019; Koçak, Ergin ve Yalçın, 2014; Yıldırım, 2008). 0-6 yaşlarda beden, dil ve zihin gelişimi çok hızı ilerlemektedir. Bu dönemdeki gelişmeler çocuğun yaşamını ve geleceğini belirleyici olmaktadır (Güneş, 2010, s. 28). Okul öncesi dönemde dil gelişimi hızlı bir seyir takip eder, bu seyrin desteklenmesi çocukta hem sosyal gelişmeyi hem de zihinsel gelişmeyi beraberinde getirir (Ayrancı, 2018, s.17). Dilin kazanılması, doğrudan çocuğun bilişsel gelişimine dayanmakta olup zihinsel uyum süreçlerinin her biri algılama, kavram geliştirme ve dilin kazanılmasıyla yakından ilişkilidir (Karacan, 2000b).

\section{Kelime Hazinesi}

Kelime hazinesi; bir bireyin ana dilinde ya da öğrendiği bir yabancı dilde bildiği, zihninde anlamlandırabildiği ve kendini ifade ederken kullandığı bütün kelimelerdir. Kelime hazinesinin iki boyutu vardır. Birincisi; anlama sürecinde duyulan, zihinde yer bulan ve anlamının bilindiği ya da bağlama göre anlamlandırılabilen kelimelerden oluşan alıcı kelime hazinesidir. İincisi ise anlatım sürecinde aktif olarak kullanılan kelimelerden oluşan üretici kelime hazinesidir.

Dilin anlaşılması kullanılmasına öncülük eder, bir başka deyişle çocuklar dili kullanmadan çok önce kelimeleri ve cümleleri anlarlar (Karacan, 2000a: 265). Yani bebeklerin henüz konuşmaya başlamadan önceki dönemlerinde alıcı kelime hazineleri işlemeye başlar. Duyulan her kelime zihinde yer alan alıcı kelime hazinesine eklenir ve duyulma sıklığına bağlı olarak bebeğin konuşmaya başladığı dönemde üretici kelime hazinesinde kullanılmaya başlar.

Dil gelişiminin önemli aşamalarından biri olan kavram geliştirme süreci yaş ve yaşantılarla ilgilidir. Bilişsel gelişim dönemine uygun olarak karşılaşılan uyarıcılarla öğrenilen kavramlar ve kelimeler artmaktadır. Böylece gelişen kelime hazinesi temel dil becerilerini desteklemektedir. Kelime hazinesi düşünce üretilmesi ve geliştirilmesi sürecinde de önemli bir rol oynar. Bu süreçte zihindeki alıcı kelime hazinesine katılan yeni kelime, kavramlar ve bunlar arasındaki ilişkiler sayesinde duygu ve düşünce dünyası zenginleşir, geliştirilen yeni duygu ve düşünceler dile kelimelerle dökülerek varlık bulur. Bu kelimelerin varlık bulması, duygu ve düşüncelerin verilmek istenen mesaja göre zihindeki üretici kelime hazinesi içinde yer alan en uygun kelimelerin seçilmesi ve dilsel kodların oluşturulması yoluyla gerçekleşir.

Çocuğun kelime hazinesini tespit etmek dil gelişimini takip etmek adına önemlidir ancak okul öncesi dönem çocuklarından sözlü veri toplamak ve çocukların kelimelerin anlamlarını gerçekten bilip bilmediklerini tespit etmek zor ve zahmetli bir iştir. Çünkü bir kelimeyi bilmek sadece söylenişini bilmek değil anlamıyla birlikte bilmek demektir. Hurlock'a göre; konuşmanın iki kriteri vardır:

1.Çocuğun söylediği kelimelerin anlamını bilmesi, çıkarılan seslerin belirli bir objeye karşılık getirilerek kullanılmasıdır.

2.Çocuğun söylediği kelimelerin, başkaları tarafından anlaşılabilecek şekilde düzgün olmasıdır. (aktaran: Özbaydar, 1970).

Dilin ustaca kullanılmasının ve inceliklerinin öğrenilmesinin 5-10 yaşları arasında olduğu kabul edilmekle birlikte, çocukların büyük bir çoğunluğu, temel dil kazanma sürecinin önemli bir bölümünü, 5-6 yaşlarında gerçekleştirmektedir. (Yapıcı, 2004, s. 6) 5 yaşındaki bir çocuk objeleri işlevlerine göre tanımlar; hız, sayı, zaman ve uzam kavramları gelişmiştir. 5-6 kelimeli cümle kurar. Birçok zıt kavramı anlar. Farklı zamanları ve çeşitli cümle kalıplarını kullanabilir. Cümleyi değişik biçimlerde kurabilir. 
Kendi yanlışlarını kendisi düzeltir. (Ayrancı, 2018; Karacan, 2000a) Bu yüzden 5 yaştan itibaren kelime hazinesini tespit etmek çok daha kolaylaşır. 48-72 ay arasındaki çocuklar üzerinde kelime hazinesi ile ilgili çalışmalar daha fazla yapılmaktadır. Ülkemizde çalışmaların çoğunda kelime hazinesinin sosyoekonomik düzey, yaş aralığı, cinsiyet, teknoloji kullanımı gibi değişkenlere göre değişip değişmediği ya da çocukların dil yapılarının nasıl bir gelişim gösterdiği araştırılmıştır. (Altun, 2019; Aydoğan ve Koçak, 2003; Savaş ve Turan, 2011; Dereli, 2003, Derman, 2017) Bu çalışmaların çoğunda okul öncesi çocuklarının kelime hazinesini ölçmek için genelde resimli kelime testlerinin uygulandığı görülmektedir. (Dereli ve Koçak, 2005; Erdoğan vd. 2005; Ergin, 2012; Eryılmaz vd., 2019; Koçak vd. 2014; Derman, 2017; Yıldırım, 2008).

Jonhston'a (1993) göre (aktaran Işıtan ve Turan, 2014, s. 108) çocuğun gerçek dil performansına ilişkin en güvenilir bilgi doğal iletişim ortamında gözlem ve dil örneği analizi ile sağlanmaktadır, bu nedenle gerçek iletişim ortamından alınan doğal dil örneği analizi değerlendirme sürecinin önemli bir parçası olarak düşünülmektedir. Ülkemizde öğrencileri konuşturarak sözlü veri elde etme yoluyla yani dil örneği alınarak yapılan çalışmalar daha azdır. (Acarlar, 2005; Aktürk, 2012; Savaş ve Turan, 2011). Kelime hazinesi belirleme çalışmalarında yazılı veya sözlü veri yoluyla elde edilen sıklık listeleri ana dil öğretiminde önemli bir yere sahiptir. Aksan (2000) bir dilde en sık kullanılan ilk 1000 kelimenin o dille yapılan üretimlerin yaklaşık \%80'ini karşıladı̆̆ını söyleyerek sıklık listelerindeki ilk 1000 kelimenin temsil gücünü ortaya koyar. Sıklık listelerinden çok daha hacimli olan derlem çalışmaları da dil öğretiminde önemlidir. Karadağ (2019a) dilin genel amaçlı olarak öğretiminde derlem temelli sıklık listelerinin veya sıklık sözlüklerinin kullanılmasının son derece işlevsel olduğunu belirterek dil öğretiminde dilde en sık kullanılan birimlerin öncelikli olarak öğretiminin hedeflendiğini vurgular. Bu yüzden her seviyede derlem temelli sıklık listeleri oluşturulması kelime öğretiminde işlevsel olarak kullanılması bakımından önemlidir. Bir dil için oluşturulmuş derlem temelli sıklık listesi dilin genel görünümünü temsil etmektedir. Böyle bir liste ile özel amaçlı hazırlanan sıklık listelerinin karşılaştırılması iki liste arasındaki ortaklığı ve ayrılığı göstermekte, böylece elde edilen veriler dil öğrenme ve öğretme sürecinde yönlendirici olmaktadır. Karadağ (2019a) genel derlemlerin dilin genel görünümünü ortaya koyduğu için bu görünümde fazla soyut kelime yer aldığını belirtir ve bu yüzden alt yaşlarda (okul öncesi ve temel eğitim düzeyi) bulunan çocukların soyut düşünce gelişimi henüz gerçekleşmediği için genel derlemlerin çocukların dil eğitiminde işlevsel olmadığını belirtir.

Bu çalışmada 60 ay ve üzeri okul öncesi çocuklarının kelime hazinesi tespit edilmiş, sıklık listesi elde edilmiş ve bu liste derlem temelli çeşitli listelerle karşılaştırılmıştır. Okul öncesi çocuklarının dil edinim sürecinde kullandıkları kelimelerin çeşitli sıklık listeleriyle ne ölçüde farklılık gösterdiğini ortaya koymak amacıyla yapılan bu çalışmada aşağıdaki sorulara cevap aranmıştır:

1. Okul öncesi çocuklarının kelime hazinesindeki ilk 1000 kelime ile Aksan ve arkadaşlarının (2017) A Frequency Dictionary of Turkish (Türkçe Sıklık Sözlüğü) adlı çalışmalarındaki ilk 1000 kelime arasında ne kadar farklıık vardır?

2. Okul öncesi çocuklarının kelime hazinesindeki ilk 1000 kelime ile Karadağ'ın (2019b) Kelime Öğretimi kitabında yer alan "Hedef Kelime Listesi"nin ilk 1000 kelimesi arasında ne kadar farklılık vardır?

3. Okul öncesi çocuklarının kelime hazinesindeki ilk 1000 kelime ile çocuk kitaplarının ilk 1000 kelimesi (Baş, 2006) arasında ne kadar farklılık vardır?

4. Okul öncesi çocuklarının kelime hazinesindeki ilk 1000 kelime ile 1. Sınıf Türkçe ders kitaplarındaki ilk 1000 kelime arasında ne kadar farklılık vardır?

5. Okul öncesi çocuklarının kelime hazinesindeki ilk 1000 kelime ile ilkokul öğrencilerinin ilk 1000 kelimesi (Karadağ 2005) arasında ne kadar farklıık vardır?

\section{Araştırmanın Modeli}

\section{Yöntem}

Araştırmada nitel araştırma yaklaşımlarından biri olan durum çalışması yöntemi kullanılmıştır. Creswell'e (2013: 97) göre durum çalışması araştırması, araştırmacının gerçek yaşam, güncel sınırlı bir sistem (bir durum) ya da belli bir zaman içerisindeki çoklu sınırlandııımış sistemler (durumlar) hakkında çoklu bilgi kaynakları (örneğin gözlemler, mülakatlar, görsel-işitsel materyaller ve dokümanlar ve 
raporlar) aracılığıyla detaylı ve derinlemesine bilgi topladığı, bir durum betimlemesi ya da durum temaları ortaya koyduğu nitel bir yaklaşımdır. Bu çalışmada birden çok durum olduğu, her bir durum bütüncül bir yaklaşımla incelendiği ve birbiriyle karşılaştırıldığı için bütüncül çoklu durum deseni kullanıımıştır. Çalışmadaki durumu, okul öncesi çocuklarının en sık kullandığı ilk 1000 kelime ile çeşitli sıklık listelerinin karşılaştırılması oluşturmaktadır.

\section{Katılımcılar ve İnceleme Nesneleri}

Araştırmanın katılımcılarını Erzincan ilinin 4 farklı bölgesinden seçilen okul öncesi eğitim kurumlarında eğitim gören 60 ay ve üzeri yaş grubundaki 17 kız, 13 erkek olmak üzere 30 çocuk oluşturmaktadır. Araştırmanın inceleme nesnesini ise söz konusu çocuklardan sözlü dil yoluyla elde edilen kelime havuzu oluşturmaktadır.

\section{Verilerin Toplanması ve Analizi}

Okul Öncesi Eğitimi Programı, okul öncesi ders kitapları, okul öncesi çocuklarının hazırbulunuşluk düzeyleri ve alan uzmanlarının görüşü alınarak çalışma için farklı 8 tema belirlenmiştir. Farklı temalar çocukların kullandığı kelimelerin çeşitliliğini tespit etmek bakımından önem taşımaktadır. Bu temalar hayal gücü, paylaşım, yardımseverlik, temizlik, kıskançlık-sevgi, aile-anne sevgisi, arkadaşlık aile bağları temalarıdır. Belirlenen temalara göre seçilen 8 hikâye kitabı için alan uzmanlarından kitapların çalışma kapsamında kullanılabilir olduğuna yönelik onay alınmış ve bu kitaplar çocuklara etkileşimli olarak okunmuştur. Çalışmada okunan kitaplar ve bilgileri Tablo 1.'de gösterilmiştir.

Tablo 1.

Araştırmada Kullanılan Çocuk Kitapları

\begin{tabular}{lllllc}
\hline Sıra & Kitabın Adı & Yazar & Yayınevi & $\begin{array}{l}\text { Sayfa } \\
\text { Sayısı }\end{array}$ & $\begin{array}{l}\text { Yayım } \\
\text { Tarihi }\end{array}$ \\
\hline 1. & $\begin{array}{l}\text { Kırmızı Fili Gördünüz } \\
\text { mü? }\end{array}$ & Ferit Avcı & $\begin{array}{l}\text { Can Çocuk } \\
\text { Yayınları }\end{array}$ & 24 & 2007 \\
\hline 2. & $\begin{array}{l}\text { Aydedeyi Saklayan } \\
\text { Çocuk }\end{array}$ & Özdilek Erdem & Kök Yayıncılık & 16 & 2002 \\
\hline 3. & $\begin{array}{l}\text { Tombik Ayı Teşekkür } \\
\text { Ediyor }\end{array}$ & $\begin{array}{l}\text { Karma Wilson-Jane } \\
\text { Chapman }\end{array}$ & Pearson Yayınları & 35 & 2015 \\
\hline 4. & Burun & Yekta Kopan & Marsık Kitap & 24 & 2009 \\
\hline 5. & Kıskanç Kurbağa Eda & Tülin Kozikoğlu & $\begin{array}{l}\text { Redhouse Kidz } \\
\text { Yayınları }\end{array}$ & 28 & 2015 \\
\hline 6. & Memo ve Ay & Alice Briere Haquet & $\begin{array}{l}\text { Mavibulut } \\
\text { Yayıncılık }\end{array}$ & 36 & 2016 \\
\hline 7. & $\begin{array}{l}\text { Minik Ayı Vadu } \\
\text { Arkadaş Arıyor }\end{array}$ & Ayfer Gürdal Ünal & $\begin{array}{l}\text { Can Çocuk } \\
\text { Yayınları }\end{array}$ & 32 & 2017 \\
\hline 8. & $\begin{array}{l}\text { Babamın Burnundan } \\
\text { Düştüm }\end{array}$ & Ayla Çınaroğlu & $\begin{array}{l}\text { Uçalık } \\
\text { Yayınları }\end{array}$ & 24 & 2010 \\
\hline
\end{tabular}

Etkileşimli okuma sırasında çocuklara kitaptaki resimler, konu ve olaylarla ilgili Whitehurts ve Zevenbergen'in (2003 ) belirlediği soru tipleri dikkate alınarak "tamamlama", "hatırlama", "açık uçlu", "ne-neden-niçin", "geliştirme" soruları sorulmuş böylelikle hikâye okuma öncesi, süresi ve sonrasında çocukların duygu ve düşüncelerini ifade etmeleri sağlanmıştır.

Uygulamalar sekiz hafta boyunca, haftada bir gün yapılmıştır ve her bir çocuk için uygulama ortalama 10 dakika sürmüştür. Etkileşimli okuma yöntemiyle hikâye okuma etkinliği yapılırken çocukların söylediği her söz ses kayıt cihazı ile kayıt altına alınmıştır. Sınıf ortamında çocukların hep bir ağızdan konuştukları ve birbirlerinin sözlerini taklit ettikleri pilot uygulamalar sırasında tespit edilmiş 
dolayısıyla çalışmanın güvenilirliğini artırmak için ve veri toplama sürecinin sağlıklı işleyebilmesi için çocuklarla uygulama sınıf ortamında ancak ders dışında yapılmıştır.

Ses kayıtları ile elde edilen 21299 kelimeden oluşan dil örneği önce bilgisayar ortamına yazı olarak aktarılmıştır. Ardından çocukların konuşma dilinde kullandıkları kelimeler, telaffuzları hatalı olan kelimeler ve ağız özelliği taşıyan kelimeler Standart Türkiye Türkçesine göre düzeltilmiştir. Rakamlar yazıyla ve aralarına (+) işareti konularak yazıımıştır. Ayrı yazılan birleşik kelimeler ve sözlükte yer almamasına rağmen kalıplaşmış olan kelimeler aralarına (+) işareti konularak yazılmıştır. Özel isimler, ayırt edilebilmeleri için "*" işareti ile deyimler ise "\#" işareti ile belirtilmiştir. Bu işlemler yapıldıktan sonra oluşturulan metin havuzu Simple Concordance 4.07 programı ile işleme tabi tutularak 21299 kelime hazinesi unsurundan oluşan kelime sıklık listesi elde edilmiştir. Listede yer alan fiillerdeki çekim ekleri ve fiilimsi ekleri atıldıktan sonra fiil kök, gövde veya tabanlarına "_" işaret konulmuştur. Aynı kök ya da gövdeye eklenmiş olan çekim ekleri atılarak bu kök veya gövdeye ait olan sıklık hesaplanarak söz konusu kelimenin sıklığına eklenmiştir. Havuzlarda yer alan eş sesli kelimeler tespit edilmiştir. Uzatılan ünlemler kısaltılarak yazılmıştır. Kelime listesinin oluşturulmasında ve analiz edilmesinde kelimelerin geçtiği yerleri ve sıklıklarını gösteren Simple Concordance Program 4.07 ile Microsoft Excel yazılımları kullanılmıştır.

Hazırlanan kelime listesi ile karşılaştırılacak olan diğer 5 liste içinde yer alan parantezli kelimelerin benzer fakat birbirinden farklı olan açıklamaları eşleştirilmiştir. Ardından listelerin ilk 1000 kelimeleri karşılaştırılmış ve böylece ortak kelimeler, bunların oranları, listelerin birbirleriyle ne kadar uyumlu oldukları ve ne kadar farklılaştıkları tespit edilmiştir.

\section{Araştırma ve Yayın Etiği}

Bu çalışmada "Yükseköğretim Kurumları Bilimsel Araştırma ve Yayın Etiği Yönergesi" kapsamında uyulması belirtilen tüm kurallara uyulmuştur. Yönergenin ikinci bölümü olan "Bilimsel Araştırma ve Yayın Etiğine Aykırı Eylemler" başlığı altında belirtilen eylemlerden hiçbiri gerçekleştirilmemiştir.

\section{Etik Kurul izni}

Kurul adı = Erzincan III Milli Eğitim Müdürlüğü

Karar tarihi $=18.10 .2017$

Belge sayı numarası $=77629021-44-E .16967303$

\section{Bulgular}

Okul Öncesi Çocuklarının Kelime Hazinesine ilişkin Bulgular ve Yorum

Tablo 2.

Okul Öncesi Çocuklarının Toplam ve Farklı Kelime Sayıları

\begin{tabular}{lll}
\hline Toplam Kelime Sayısı & Farklı Kelime Sayısı & Toplam/Farklı Kelime Oranı \\
\hline 21299 & 1732 & 12,29 \\
\hline
\end{tabular}

Tablo 2., 60 ay ve üstü okul öncesi çocuklarının etkileşimli okuma yapılarak elde edilen sözlü verilere göre kullandıkları toplam kelime sayısının 21.299 olduğunu göstermektedir. Çocukların kullandığı birbirinden farklı kelime sayısı ise 1732 'dir. Toplam kelimelerin farklı kelimelere oranı 12,29 'dur. Bu bulgu çocukların konuşmalarında geçen her farklı kelimenin ortalama olarak 12,29 kez tekrar ettiğini göstermektedir. 
Tablo 3.

Okul Öncesi Çocuklarının IIlk 1000 Kelimesi

\begin{tabular}{|c|c|c|c|c|c|c|c|c|c|}
\hline S. & Kelimeler & 105 & bul- & 49 & daha & 31 & diş & 22 & ara- \\
\hline 810 & da/de & 103 & al- & 49 & doğru & 31 & hem & 22 & benze- \\
\hline 697 & 0 & 98 & burun & 49 & küçük & 31 & kal- & 22 & benzet- \\
\hline 630 & bir & 94 & belki & 48 & köpek & 30 & kuş & 22 & bütün \\
\hline 505 & çünkü & 94 & yer & 48 & paylaş- & 29 & aklına gel- & 22 & dolap \\
\hline 493 & ben (zamir) & 92 & işte & 48 & üst & 29 & dışarı çık- & 22 & hediye et- \\
\hline 399 & bil- & 91 & bir tane & 47 & ee & 29 & gir- & 22 & ile \\
\hline 379 & şey & 88 & gör- & 47 & iki & 29 & kötü & 22 & kadar \\
\hline 362 & ol- & 87 & güzel & 47 & iyi & 28 & gece & 22 & kız \\
\hline 327 & olabil- & 85 & ne & 46 & çamur & 28 & ışık & 22 & uzun \\
\hline 313 & oyna- & 85 & ora & 45 & bebek & 28 & izle- & 22 & zürafa \\
\hline 298 & çok & 82 & diye & 45 & değil & \multirow[t]{2}{*}{28} & \multirow{2}{*}{$\begin{array}{l}\text { teşekkür } \\
\text { et- }\end{array}$} & 21 & ağız \\
\hline 290 & için & 75 & ver- & 44 & bazen & & & 21 & at- \\
\hline 288 & anne & 72 & ayı & 44 & ilgili & 27 & fırçala- & 21 & çalış- \\
\hline 274 & başka & 72 & hiç & 43 & bura & 27 & o yüzden & 21 & falan \\
\hline 259 & var & 71 & yani & 43 & düşün- & 27 & sen & 21 & temizle- \\
\hline 249 & arkadaş & 71 & yıka- & 42 & herkes & 26 & aç- & 21 & ye- \\
\hline 240 & yap- & 69 & hiçbir & 42 & topla- & 26 & ayak & 20 & aynı \\
\hline 226 & sonra & 68 & düş & 41 & yemek & 26 & kıskan- & 20 & bir kere \\
\hline 214 & iste- & 68 & getir- & 40 & en (zarf) & 26 & uyu- & 20 & biraz \\
\hline 207 & git- & 67 & yardım et- & 40 & kurbağa & 26 & yan & 20 & dur- \\
\hline 205 & sev- & 65 & ya da & 40 & nasıl & 25 & bile & 20 & gerek- \\
\hline 190 & de- & \multirow[t]{2}{*}{64} & \multirow{2}{*}{$\begin{array}{l}\text { hayır } \\
\text { (xevet) }\end{array}$} & 39 & araba & 25 & çağır- & 20 & hemen \\
\hline 172 & ama & & & 39 & şu & 25 & çiçek & 20 & kaç- \\
\hline 171 & yok & 63 & ay dede & 39 & top & 25 & karanlık & 20 & koy- \\
\hline 166 & $\mathrm{ki}$ & 63 & söyle- & 38 & kardeş & 25 & yemek ye- & 20 & leylek \\
\hline 159 & gel- & 62 & kendi & 38 & şöyle & 24 & fikir & 20 & üzgün \\
\hline 154 & biz & 62 & üzül- & 38 & yağmur & 24 & kaybol- & 20 & yatak \\
\hline \multirow[t]{2}{*}{154} & \multirow{2}{*}{$\begin{array}{l}\mathrm{mı} / \mathrm{mi} / \mathrm{mu} / \\
\mathrm{mü}\end{array}$} & 62 & zaman & 37 & büyük & 24 & mikrop & 20 & zorlan- \\
\hline & & 60 & el (organ) & 37 & sadece & 24 & saç & 19 & Allah \\
\hline 151 & böyle & 60 & hayvan & 37 & tavşan & 24 & yardım & 19 & aa \\
\hline 151 & çık- & 58 & merdiven & 36 & zıpla- & 23 & abla & 19 & ağaç \\
\hline 146 & oyuncak & 57 & her & 35 & güneş & 23 & bir sürü & 19 & amca \\
\hline 144 & ay (uydu) & 57 & ya (bağlaç) & 34 & bırak- & 23 & hepsi & 19 & göz \\
\hline 143 & evet & 57 & yüz (çehre) & 34 & iç & 23 & hikâye & 19 & kalp \\
\hline 141 & mesela & 55 & hep & 34 & okul & 23 & koş- (koşu) & 19 & karın \\
\hline 139 & oyun & 54 & gibi & 33 & tabii & 23 & nere & 19 & kulak \\
\hline 117 & çocuk & 53 & öyle & & (elbette) & 23 & oda & 19 & tablet \\
\hline 117 & ve & 52 & bak- & 33 & unut- & 23 & Su & 19 & temiz \\
\hline 112 & fil & 51 & biri & 32 & balık & 23 & tane & 19 & tırman- \\
\hline 106 & bu & 51 & dışarı & 32 & doktor & 23 & yat- & 18 & büyü- \\
\hline 106 & ev & 51 & kedi & 32 & zaten & 22 & canı sıkıl- & 18 & hı (ünlem) \\
\hline 105 & baba & 50 & insan & 31 & akşam & 22 & ad & 18 & kandır- \\
\hline
\end{tabular}




\begin{tabular}{|c|c|c|c|c|c|c|c|c|c|}
\hline 18 & kırmızı & 14 & tut- & 11 & dünya & 9 & Ebrar & 8 & kat \\
\hline 18 & o kadar & 14 & yürü- & 11 & erkek & 9 & acı- (ağrı) & 8 & kez \\
\hline 18 & sevin- & 13 & adam & 11 & et- & 9 & anneanne & 8 & kıyafet \\
\hline 18 & telefon & 13 & arkadaş ol- & 11 & gez- & 9 & ara & 8 & kirli \\
\hline 17 & Barbie & 13 & belli et- & 11 & içeri & 9 & ayak izi & 8 & kok- \\
\hline 17 & ağla- & 13 & diğer & 11 & kafa & 9 & azıcık & 8 & koltuk \\
\hline 17 & niye & 13 & hadi & 11 & kapı & 9 & bahçe & 8 & kule \\
\hline 17 & önce & 13 & hava & 11 & kaybet- & 9 & baş & 8 & küs- \\
\hline 17 & saklan- & 13 & karga & 11 & köstebek & 9 & beğen- & 8 & sarı \\
\hline 17 & şimdi & 13 & kocaman & 11 & neden & 9 & değiştir- & 8 & siyah \\
\hline 17 & zor & 13 & organ & 11 & oynayabil- & 9 & dev & 8 & sor- \\
\hline 16 & artık & 13 & sabah & 11 & tatlı & 9 & doğur- & 8 & soru \\
\hline \multirow[t]{3}{*}{16} & \multirow{3}{*}{$\begin{array}{l}\text { bit- } \\
\text { (tükenmek } \\
\text { ) }\end{array}$} & 13 & saklambaç & 11 & yanlış & 9 & dön- & 8 & tam \\
\hline & & 13 & san- & 11 & yazı (nesir) & 9 & elbise & 8 & tuvalet \\
\hline & & \multirow[t]{2}{*}{13} & \multirow{2}{*}{$\begin{array}{l}\text { şura (şu } \\
\text { yer) }\end{array}$} & 10 & arka & 9 & görebil- & 8 & uzat- \\
\hline 16 & doğ- & & & 10 & az & 9 & hatta & 8 & yaramazlık \\
\hline 16 & hediye & 13 & tamam & 10 & başla- & 9 & Islan- & 7 & özür dile- \\
\hline 16 & iş & 13 & tanı- & 10 & birazcık & 9 & kişi & 7 & akıl \\
\hline 16 & oku- & 13 & uç- & 10 & birlikte & 9 & kullan- & 7 & alabil- \\
\hline 16 & ön & 13 & yaş (ömür) & 10 & çek- & 9 & sür- & 7 & annecik \\
\hline 16 & park & 13 & yıldız & 10 & çıkar- & 9 & taş & 7 & as- \\
\hline 16 & vur- & 13 & yine & 10 & çöp & 9 & televizyon & 7 & aydınlat- \\
\hline 16 & yağ- & 12 & bu kadar & 10 & dağınık & \multirow[t]{2}{*}{9} & \multirow{2}{*}{$\begin{array}{l}\text { yorul- } \\
\text { (yorgun) }\end{array}$} & 7 & aydınlık \\
\hline 16 & zıp zıp & 12 & çıkabil- & 10 & davran- & & & \multirow[t]{2}{*}{7} & \multirow{2}{*}{$\begin{array}{l}\text { boy } \\
\text { (uzunluk) }\end{array}$} \\
\hline 15 & alt & 12 & eğer & 10 & devam & 9 & yukarı & & \\
\hline 15 & besle- & 12 & eşya & 10 & geç- & 8 & izin al- & 7 & boya- \\
\hline 15 & cam & 12 & gözlük & 10 & hasta & 8 & açık & 7 & cık (ünlem) \\
\hline 15 & duvar & 12 & hani & 10 & hatırla- & 8 & ağ (örgü) & 7 & çimen \\
\hline 15 & götür- & 12 & her zaman & 10 & her gün & 8 & aile & 7 & çukur \\
\hline 15 & pis & 12 & kirlen- & 10 & hisset- & 8 & anlat- & 7 & dört \\
\hline 15 & tak- & 12 & mutlu ol- & 10 & kâğıt & 8 & babaanne & 7 & duy- \\
\hline 15 & yan- & 12 & otur- & 10 & kahvaltı & 8 & bacak & 7 & gül \\
\hline 15 & yastık & 12 & resim & 10 & kay- & 8 & balon & 7 & hangi \\
\hline 14 & anla- & 12 & taraf & 10 & kes- & 8 & bas- & 7 & in- \\
\hline 14 & ayıcık & 12 & uzak & 10 & kız- & 8 & bazı & 7 & izin ver- \\
\hline 14 & birbiri & 12 & yapabil- & 10 & konuş- & 8 & becerikli & 7 & kaktüs \\
\hline 14 & durum & 12 & yıkan- & 10 & kork- & 8 & boyama & 7 & kır- \\
\hline 14 & hım & 12 & yoo & 10 & lazım & 8 & bugün & 7 & kolye \\
\hline 14 & kalk- & 11 & $a b i$ & 10 & öğretmen & 8 & bulut & 7 & lavabo \\
\hline 14 & kitap & 11 & ateş & 10 & özle- & 8 & gerekli & 7 & merak et- \\
\hline 14 & komşu & 11 & ayakkabı & 10 & parça & 8 & giyin- & 7 & normal \\
\hline 14 & mutlu & 11 & baykuş & 10 & sağ (yön) & 8 & gün & 7 & oynat- \\
\hline 14 & özelik & 11 & bin- & 10 & tek & 8 & hiç kimse & 7 & örümcek \\
\hline 14 & rüzgâr & 11 & boş & 10 & yeni & 8 & iç- & 7 & para \\
\hline 14 & sıkıl- & 11 & çizgi film & 9 & ali & 8 & kapat- & 7 & pasta \\
\hline
\end{tabular}




\begin{tabular}{|c|c|c|c|c|c|c|c|c|c|}
\hline 7 & sarıl- & 6 & sallan- & 5 & uçak & 4 & ip & 4 & uzay \\
\hline 7 & takıl- & 6 & sanki & 5 & yapıştır- & 4 & kabuk & 4 & yaprak \\
\hline 7 & tekrar & 6 & say- & 5 & yeşil & 4 & kanat & 4 & yaramaz \\
\hline 7 & temizlen- & 6 & seç- & 5 & yiyecek & \multirow[t]{2}{*}{4} & \multirow{2}{*}{$\begin{array}{l}\text { kaplumbağ } \\
\text { a }\end{array}$} & 4 & yetiş- \\
\hline 7 & üç & 6 & sıkış- & 5 & yüksek & & & 4 & yoksa \\
\hline 7 & yak- (ateş) & 6 & silah & 5 & yüzük & 4 & kaydırak & 4 & yorgun \\
\hline 7 & yarat- & 6 & spor & \multirow[t]{2}{*}{4} & \multirow{2}{*}{$\begin{array}{l}\text { dünyaya } \\
\text { gel- }\end{array}$} & 4 & kaz- & 4 & yüz- (suda) \\
\hline 7 & yaşa- & 6 & sümük & & & 4 & keşke & 3 & güneş aç- \\
\hline 7 & yavru & 6 & tüm & 4 & söz dinle- & 4 & kısa & 3 & güneş doğ- \\
\hline 6 & canı iste- & 6 & yakala- & \multirow[t]{2}{*}{4} & \multirow{2}{*}{$\begin{array}{l}\text { Ahmet } \\
\text { Enes }\end{array}$} & 4 & kirpi & 3 & Işık tut- \\
\hline 6 & şaka yap- & 6 & yalan & & & 4 & kurtar- & 3 & Ankara \\
\hline 6 & Counter & 5 & geri dön- & 4 & Dadu & 4 & küçücük & 3 & Ece \\
\hline 6 & GTA & 5 & eda & 4 & ak- & 4 & leke & 3 & Ecrin \\
\hline 6 & ayrıl- & 5 & astronot & 4 & bat- & 4 & masa & 3 & Elif \\
\hline 6 & banyo & 5 & aşağı & 4 & bekle- & 4 & masal & 3 & Erzurum \\
\hline 6 & bardak & 5 & at & 4 & beri & 4 & mekik & 3 & Eylül \\
\hline 6 & beraber & 5 & atla- & 4 & beyaz & 4 & nefes al- & 3 & Iphone \\
\hline 6 & beş & 5 & banyo yap- & 4 & bir daha & 4 & orta & 3 & Kerim \\
\hline 6 & bisiklet & 5 & bilgisayar & 4 & bomboş & 4 & oysa & 3 & Kürşat abi \\
\hline 6 & bulaşık & 5 & bir parça & 4 & cadı & 4 & öl- & 3 & örümcek \\
\hline 6 & çıkart- & 5 & çatı & 4 & canavar & 4 & öp- & & adam \\
\hline 6 & çiz- & 5 & çok çok & 4 & çivi & 4 & özel & 3 & pitbul \\
\hline 6 & dede & 5 & damla & 4 & dağıt- & 4 & özel & 3 & Winks \\
\hline 6 & düşür- & 5 & devam et- & 4 & dakika & & harekat & 3 & Zeynep \\
\hline 6 & eğik & 5 & döv- & 4 & dans et- & 4 & parlak & 3 & zuma \\
\hline 6 & eğlenceli & 5 & dürbün & 4 & davranış & 4 & parti & 3 & açıl- \\
\hline 6 & eski & 5 & farklı & 4 & diş fırçası & 4 & perde & 3 & ağır \\
\hline 6 & göster- & 5 & gerçek & 4 & $\begin{array}{l}\text { doğum } \\
\text { günü }\end{array}$ & 4 & piknik yap- & 3 & aha \\
\hline 6 & hizlı & 5 & gündüz & 4 & $\begin{array}{l}\text { gunu } \\
\text { dokun- }\end{array}$ & 4 & pil & 3 & altı \\
\hline 6 & inan- & 5 & ha & 4 & (temas) & 4 & pişir- & 3 & altın \\
\hline 6 & indir- & 5 & hazırla- & 4 & düzgün & 4 & robot & 3 & anlatabil- \\
\hline 6 & isim & 5 & hortum & 4 & e (harf) & 4 & saat & 3 & apartman \\
\hline 6 & iş yap- & 5 & kaybolabil- & 4 & eskiden & 4 & sofra & 3 & ara sıra \\
\hline 6 & kırıl- & 5 & kızdır- & 4 & fazla & 4 & sohbet et- & 3 & aslında \\
\hline 6 & kokarca & 5 & kim & 4 & falan & 4 & Söz & 3 & AVM \\
\hline 6 & kol & 5 & kimse & 4 & film & 4 & sürekli & 3 & aydınlan- \\
\hline 6 & kolay & 5 & köy & 4 & giy- & 4 & sürpriz & 3 & aydınlatabi \\
\hline 6 & kopar- & 5 & kucak & 4 & gökyüzü & 4 & şar] & & \\
\hline 6 & kuzen & 5 & ortalık & 4 & hamur & 4 & şarkı & 3 & ayır- \\
\hline 6 & lahana & 5 & öbür & 4 & hapşır- & 4 & şeker & 3 & bal \\
\hline 6 & meyve & 5 & patla- & 4 & harf & 4 & şimşek çak- & 3 & balkon \\
\hline 6 & mutfak & 5 & roket & 4 & herhalde & 4 & tren & 3 & bence \\
\hline 6 & piknik & 5 & sil- & 4 & ihtiyacı ol- & 4 & ulaş- & 3 & beş buçuk \\
\hline 6 & renk & 5 & süpürge & 4 & ilk & 4 & uyan- & 3 & bileklik \\
\hline 6 & sakla- & 5 & tanış- & 4 & inek & 4 & uyut- & 3 & bin \\
\hline
\end{tabular}




\begin{tabular}{|c|c|c|c|c|c|c|c|c|c|}
\hline 3 & bir defa & 3 & kapak & 3 & taşı- & 2 & Antep & 2 & bayram \\
\hline 3 & bodrum & 3 & karar & 3 & tek başına & 2 & Çaki & 2 & bekçi \\
\hline 3 & boya & 3 & kavuş- & 3 & temizlik & 2 & Efe & \multirow[t]{2}{*}{2} & belli \\
\hline 3 & bu yüzden & 3 & kayıp & \multirow[t]{2}{*}{3} & temizlik & 2 & Elsa & & (malum) \\
\hline 3 & bulaş- & \multirow[t]{2}{*}{3} & \multirow{2}{*}{$\begin{array}{l}\text { kendi } \\
\text { başına }\end{array}$} & & yap- & 2 & Emir & 2 & bıçak \\
\hline 3 & buzdolabı & & & 3 & tepe & 2 & Emregil & 2 & bir an \\
\hline 3 & can & 3 & kere & 3 & terle- & 2 & Esra+abla & 2 & birikinti \\
\hline 3 & çabuk & 3 & kesil- & 3 & teyze & 2 & Güney & 2 & birkaç \\
\hline 3 & çal- & 3 & kızgın & 3 & tırmanabil- & 2 & İstanbul & 2 & bisküvi \\
\hline 3 & çanta & 3 & kokla- & 3 & tırnak & 2 & İzmit & 2 & bitir- \\
\hline 3 & çarp- & 3 & komik & 3 & tilki & 2 & Kocaeli & 2 & bozul- \\
\hline 3 & çekmece & 3 & körebe & 3 & titre- & 2 & Kuzey & 2 & böcek \\
\hline 3 & çilek & 3 & kutu & 3 & toplan- & 2 & Maşa & 2 & böylece \\
\hline 3 & değişik & 3 & makas & 3 & toplantı & \multirow[t]{2}{*}{2} & \multirow{2}{*}{$\begin{array}{l}\text { Mehmet } \\
\text { Ali }\end{array}$} & 2 & bülbül \\
\hline 3 & dil (organ) & 3 & malzeme & 3 & toprak & & & 2 & cennet \\
\hline 3 & doğa & 3 & market & 3 & uzan- & 2 & Melek & 2 & cevap \\
\hline 3 & dol- & 3 & mavi & 3 & uzay aracı & 2 & Memo & 2 & cırmala- \\
\hline 3 & dolu (xboş) & 3 & misafir & \multirow[t]{2}{*}{3} & \multirow{2}{*}{$\begin{array}{l}\text { uzay } \\
\text { gemisi }\end{array}$} & 2 & Neslişah & 2 & cimcikle- \\
\hline 3 & dost & 3 & mutluluk & & & 2 & Nilüfer & 2 & civciv \\
\hline 3 & dök- & 3 & oğlan & 3 & üzüntü & 2 & OMP & 2 & çak- \\
\hline 3 & dökül- & 3 & otobüs & 3 & valla & \multirow[t]{2}{*}{2} & \multirow{2}{*}{$\begin{array}{l}\text { Pamuk } \\
\text { Prenses }\end{array}$} & 2 & çamaşır \\
\hline 3 & düşebil- & 3 & oturabil- & 3 & veya & & & 2 & çamurlu \\
\hline 3 & düz & 3 & ödev & 3 & video & 2 & Raşit & 2 & çapak \\
\hline 3 & eğlen- & 3 & paket & 3 & vücut & 2 & Rümeysa & \multirow[t]{2}{*}{2} & \multirow{2}{*}{$\begin{array}{l}\text { çay } \\
\text { (içecek) }\end{array}$} \\
\hline 3 & etkinlik & 3 & panda & 3 & ya (ünlem) & 2 & Tombik Ayı & & \\
\hline 3 & fener & 3 & parende & 3 & yakın & 2 & Yusuf & 2 & çekiç \\
\hline 3 & filan & 3 & parmaklık & 3 & yaklaş- & 2 & ağrıyabil- & 2 & çevir- \\
\hline 3 & geçin- & 3 & pek & 3 & yanlışlık & 2 & akıllı & 2 & çıplak \\
\hline 3 & geri & 3 & peri & 3 & yem & 2 & alt değiştir- & 2 & çiçek \\
\hline 3 & gine & 3 & polis & 3 & yer çekimi & 2 & an (zaman) & 2 & çikolata \\
\hline 3 & güçlü & 3 & sağla- & 3 & yet- & 2 & annemgil & 2 & çirkin \\
\hline 3 & gül- & 3 & salıncak & 3 & yol & 2 & arkadaşıı & 2 & çizgili \\
\hline \multirow[t]{2}{*}{3} & \multirow{2}{*}{ hala(henüz } & 3 & sert & 3 & yuvarlak & 2 & asıl- & 2 & çoban \\
\hline & & 3 & ses & 3 & yuvarlan- & 2 & ayılı & 2 & değ- \\
\hline 3 & hastalık & 3 & silahçılık & 3 & zıplayabil- & 2 & ayıp & 2 & deli \\
\hline 3 & hava karar- & 3 & sinirlen- & 2 & canı acl- & 2 & ayrıca & 2 & deniz \\
\hline 3 & havuç & 3 & siz & 2 & güneş bat- & 2 & babasıgil & 2 & deprem \\
\hline 3 & hey & 3 & soğuk & 2 & güneş bat- & 2 & bağ (ilgi) & 2 & deri \\
\hline 3 & hık & 3 & son & 2 & kalbi kırıl- & 2 & bahset- & 2 & derinlik \\
\hline 3 & hurdalık & 3 & sula- & 2 & nefes al- & 2 & bakabil- & 2 & dışarı \\
\hline 3 & ilaç & 3 & şeytan & 2 & öyle gel- & 2 & balina & & çıkabil- \\
\hline 3 & ilk önce & 3 & tabak & 2 & söz ver- & 2 & basit & 2 & diken \\
\hline 3 & isteyebil- & 3 & tahmin et- & 2 & vakit geçir- & 2 & başka biri & 2 & dikkat et- \\
\hline 3 & kandırıl- & 3 & tara- & 2 & yazık ol- & 2 & başörtü & 2 & dinozor \\
\hline 3 & kap- & 3 & tarif et- & 2 & Alperen & 2 & bayağı & 2 & dinle- \\
\hline
\end{tabular}




\begin{tabular}{|c|c|c|c|c|c|c|c|}
\hline 2 & diyebil- & 2 & hastane & 2 & kıl & 2 & saldır- \\
\hline 2 & dolaş- & 2 & havuz & 2 & kıvırcık & 2 & salon \\
\hline 2 & domuz & 2 & hayal & 2 & koca & 2 & sandalye \\
\hline 2 & dondurma & \multirow[t]{2}{*}{2} & \multirow{2}{*}{$\begin{array}{l}\text { hayvanat } \\
\text { bahçesi }\end{array}$} & 2 & konu & 2 & sat- \\
\hline 2 & doy- & & & 2 & kop- & 2 & satranç \\
\hline 2 & dönüş- & 2 & hiz & 2 & kovala- & 2 & sebze \\
\hline 2 & dua & 2 & hopla- & 2 & kötülük & & \\
\hline 2 & duman & 2 & hoşlan- & 2 & kukla & & \\
\hline 2 & duş & 2 & ISIn- & 2 & kullanabil- & & \\
\hline 2 & düzenle- & 2 & Işıldat- & 2 & kuyruk & & \\
\hline 2 & edin- & 2 & Işın & 2 & küs & & \\
\hline 2 & eğ- & 2 & iğne & 2 & lunapark & & \\
\hline 2 & elbiseli & 2 & ihtiyaç & 2 & maç & & \\
\hline 2 & elektrik & 2 & ileri & 2 & makine & & \\
\hline 2 & emek & 2 & ilgilen- & 2 & mangal & & \\
\hline 2 & engelle- & 2 & iyileştir- & 2 & minder & & \\
\hline 2 & erken & 2 & izlet- & 2 & minnacık & & \\
\hline 2 & etek & 2 & kaçırabil- & 2 & mutlu et- & & \\
\hline 2 & evcilik & 2 & kadarcık & 2 & nehir & & \\
\hline 2 & ezebil- & 2 & kafes & 2 & neyse & & \\
\hline 2 & fırça & 2 & kaldır- & 2 & odun & & \\
\hline 2 & firlat- & 2 & kalemtraş & 2 & oluş- & & \\
\hline 2 & galiba & 2 & kalpli & 2 & 000 & & \\
\hline 2 & gaz & 2 & kana- & 2 & otomatik & & \\
\hline 2 & geçir- & 2 & kanepe & 2 & otuz beş & & \\
\hline 2 & gene & & (çekyat) & 2 & Oyun & & \\
\hline 2 & gezme & 2 & kapalı & & bilgisayarı & & \\
\hline 2 & gidebil- & 2 & kara (renk) & 2 & öğrenci & & \\
\hline 2 & giydir- & 2 & karınca & 2 & öldür- & & \\
\hline 2 & gök & 2 & karışık & 2 & önceden & & \\
\hline 2 & gönder- & 2 & karıştır- & 2 & örtü & & \\
\hline 2 & göre & 2 & karşı & 2 & özgür & & \\
\hline $\begin{array}{l}2 \\
2\end{array}$ & $\begin{array}{l}\text { gore } \\
\text { görün- }\end{array}$ & 2 & kart (kâğıt) & 2 & pahalı & & \\
\hline$\frac{2}{2}$ & görüş- & 2 & kaş & 2 & parfüm & & \\
\hline 2 & gözük- & 2 & kat- & 2 & pati & & \\
\hline 2 & güçlen- & 2 & katla- & 2 & pazar & & \\
\hline 2 & güldür- & 2 & kavga et- & 2 & peçete & & \\
\hline 2 & güleryüz & 2 & kazan- & 2 & peş & & \\
\hline 2 & gürle- & 2 & kelebek & 2 & pırıltılı & & \\
\hline$\frac{2}{2}$ & güven- & 2 & kenar & 2 & püskürtebil & & \\
\hline 2 & guven- & 2 & kendi & & - & & \\
\hline 2 & halı & & kendine & 2 & reklam & & \\
\hline 2 & hamak & 2 & kepçe & 2 & renkli & & \\
\hline 2 & harita & 2 & kesin & 2 & sade & & \\
\hline 2 & hasta et- & 2 & kestir- & 2 & sakal & & \\
\hline
\end{tabular}


Tablo 3'e bakıldığında diğer sıklık listelerinde olduğu gibi “da/de, o, bir, ben" gibi kelimelerin en çok tekrar eden kelimeler olduğu görülmektedir. Bu listedeki en fazla kullanılan ilk 100 kelimenin bazıları cümle içinde türlerine göre incelendiğinde farklı tür kategorisinde değerlendirilebilmekle birlikte liste görünümünde, kelime bazında bakıldığında türlerin oranları şöyledir: Kelimelerin \%36'sı isim, \%23'ü fiil, \%11'i zarf, \%11'i zamir, \%9'u edat, \%9'u bağlaç, \%1'i ünlemdir.

Listede çocukların dünyasında önemli yeri olan isimlerden "anne, arkadaş, oyuncak, oyun, çocuk, fil, baba, ayı, düş, ay dede, hayvan, kedi, köpek, bebek"; fiillerden ise "oyna-, sev-, iste-, üzül-, paylaş-" gibi kelimelerin sıklıkları fazladır. En fazla kullanılan bağlaç listenin en sık kullanılan dördüncü kelimesi olan "çünkü" bağlacıdır. En sık kullanılan zarflar "çok, sonra", en sık kullanılan zamirler "o, ben", en sık kullanılan edatlar ise "için, $\mathrm{mı} / \mathrm{mi}$, böyle" dir.

Okul Öncesi Çocuklarının ilk 1000 Kelimesi ile Aksan ve Arkadaşlarının (2017) A Frequency Dictionary of Turkish (Türkçe Sıkık Sözlüğ̈̈) Adlı Çalışmalarındaki ilk 1000 Kelimenin Karşılaştırılmasına Yönelik Bulgular

Okul öncesi çocuklarının kullandığı ilk 1000 kelime ile Türkçe Sıklık Sözlüğü’nün ilk 1000 kelimesi birleştirildiğinde ortaya çıkan listedeki birbirinden farklı kelimelerin sayısı 1741'dir. Her iki listede yer alan ortak kelimelerin sayısı 254 'tür. Buna göre iki sıklık listesi \%25,4 oranında uyumludur ve iki liste birbirinden $\% 74,6$ oranında farklılaşmaktadır.

İki listede ortak olan 254 kelime alfabetik olarak aşağıda verilmiştir.

Tablo 4.

Ortak Kelime Listesi

$\begin{array}{lllll}\text { adam } & \text { ben (zamir) } & \text { davran- } & \text { eski } & \text { hayal } \\ \text { ağabey } & \text { benze- } & \text { de- } & \text { et- } & \text { hayvan } \\ \text { ağla- } & \text { beraber } & \text { değ- } & \text { etkinlik } & \text { hem } \\ \text { aile } & \text { beri } & \text { değil } & \text { ev } & \text { hemen } \\ \text { ak- } & \text { besle- } & \text { deniz } & \text { evet } & \text { hep } \\ \text { al- } & \text { beyaz } & \text { devam } & \text { falan } & \text { hepsi } \\ \text { alt } & \text { bil- } & \text { diğer } & \text { fazla } & \text { her } \\ \text { ama } & \text { bile } & \text { dinle- } & \text { fikir } & \text { herhalde } \\ \text { anla- } & \text { bilgisayar } & \text { diye } & \text { film } & \text { herkes } \\ \text { anne } & \text { bin- } & \text { doğ- } & \text { gece } & \text { hisset- } \\ \text { araba } & \text { bir } & \text { doğa } & \text { gel- } & \text { ile } \\ \text { arka } & \text { biraz } & \text { doğru } & \text { gerek- } & \text { ileri } \\ \text { at- } & \text { birbiri } & \text { doktor } & \text { gerekli } & \text { ilgilen- } \\ \text { atla- } & \text { biri } & \text { dol- } & \text { geri } & \text { ilgili } \\ \text { ay (uydu) } & \text { birlikte } & \text { dost } & \text { getir- } & \text { ilk } \\ \text { ayak } & \text { biz } & \text { dur- } & \text { gez- } & \text { in- } \\ \text { az } & \text { boy(uzunluk) } & \text { durum } & \text { gibi } & \text { inan- } \\ \text { baba } & \text { bu } & \text { duş } & \text { gir- } & \text { insan } \\ \text { bağ (ilgi) } & \text { bul- } & \text { duvar } & \text { git- } & \text { isim } \\ \text { bahset- } & \text { bura } & \text { duy- } & \text { giy- } & \text { iste- } \\ \text { bak- } & \text { can } & \text { eğer } & \text { hangi } & \text { iyi } \\ \text { bas- } & \text { cevap } & \text { el (organ) } & \text { hani } & \text { izle- } \\ \text { bazen } & \text { çiçek } & \text { en (zarf) } & \text { hasta } & \text { kadar } \\ \text { bebek } & \text { da (de) } & \text { engelle- } & \text { hastane } & \text { kafa } \\ \text { bekle- } & \text { daha } & \text { erkek } & \text { hatta } & \text { kal- } \\ \text { belki } & \text { dakika } & \text { erken } & \text { hava } & \text { kalk- }\end{array}$




$\begin{array}{lllll}\text { kalp } & \text { kullan- } & \text { parti } & \text { sor- } & \text { uzun } \\ \text { kap- } & \text { kurtar- } & \text { pazar } & \text { soru } & \text { var } \\ \text { kara (renk) } & \text { kuş } & \text { pek } & \text { spor } & \text { ve } \\ \text { karar } & \text { makine } & \text { polis } & \text { su } & \text { ver- } \\ \text { kat- } & \text { malzeme } & \text { renk } & \text { şu } & \text { veya } \\ \text { kay- } & \text { masa } & \text { resim } & \text { tabii (elbette) } & \text { vur- } \\ \text { kaybet- } & \text { mesela } & \text { saat } & \text { tak- } & \text { yağ- } \\ \text { kazan- } & \text { mutlu } & \text { sabah } & \text { tam } & \text { yakala- } \\ \text { kenar } & \text { ne } & \text { sadece } & \text { tamam } & \text { yan } \\ \text { kendi } & \text { neden } & \text { sağla- } & \text { tane } & \text { yani } \\ \text { kere } & \text { nere } & \text { sakla- } & \text { taraf } & \text { yap- } \\ \text { kes- } & \text { niye } & \text { salon } & \text { tek } & \text { yarat- } \\ \text { kesin } & \text { normal } & \text { san- } & \text { tekrar } & \text { yat- } \\ \text { kez } & \text { o } & \text { sanki } & \text { telefon } & \text { yatak } \\ \text { ki } & \text { oda } & \text { sat- } & \text { televizyon } & \text { ye- } \\ \text { kim } & \text { oku- } & \text { say- } & \text { tepe } & \text { yemek } \\ \text { kimse } & \text { okul } & \text { sen } & \text { top } & \text { yeni } \\ \text { kitap } & \text { ol- } & \text { ses } & \text { topla- } & \text { yer } \\ \text { kol } & \text { ora } & \text { sev- } & \text { toprak } & \text { yet- } \\ \text { kolay } & \text { orta } & \text { sil- } & \text { tut- } & \text { yine } \\ \text { konu } & \text { otur- } & \text { silah } & \text { unut- } & \text { yok } \\ \text { kop- } & \text { oyna- } & \text { siz } & \text { uyan- } & \text { yol } \\ \text { kork- } & \text { oyun } & \text { soğuk } & \text { uyu- } & \text { zaman } \\ \text { koy- } & \text { ol- } & \text { son } & \text { uzak } & \text { zaten } \\ \text { kulak } & \text { para } & \text { sonra } & \text { uzan- } & \text { zor }\end{array}$

Okul Öncesi Çocuklarının ilk 1000 Kelimesi ile Karadağ’ın (2019b) Kelime Öğretimi Kitabında Yer Alan "Hedef Kelime Listesi”ndeki ilk 1000 Kelimenin Karşılaştırılmasına Yönelik Bulgular

Okul öncesi çocuklarının kullandığı ilk 1000 kelime ile Karadağ'ın Hedef Kelime Listesindeki ilk 1000 kelime birleştirildiğinde ortaya çıkan listedeki birbirinden farklı kelimelerin sayısı 1445'tir. Her iki listede de yer alan ortak kelimelerin sayısı 536'dır. Buna göre iki sıklık listesinde \%53,6 oranında uyum olduğu görülmektedir. İki liste birbirinden \%46,4 oranında farklılaşmaktadır.

íki listede ortak olan 536 kelime alfabetik olarak aşağıda verilmiştir.

Tablo 5.

Ortak Kelime Listesi

$\begin{array}{lllll}\text { abla } & \text { akıl } & \text { anlatabil- } & \text { as- } & \text { aynı } \\ \text { aç- } & \text { aksam } & \text { anne } & \text { aşağı } & \text { ayrıca } \\ \text { açık } & \text { al- } & \text { anneanne } & \text { aslında } & \text { ayrıl- } \\ \text { acil- } & \text { alabil- } & \text { apartman } & \text { at } & \text { az } \\ \text { adam } & \text { alt } & \text { ara- } & \text { at- } & \text { baba } \\ \text { ağabey } & \text { altın } & \text { araba } & \text { ateş } & \text { babaanne } \\ \text { ağaç } & \text { ama } & \text { arka } & \text { atla- } & \text { bacak } \\ \text { ağız } & \text { amca } & \text { arkadaş } & \text { ay (uydu) } & \text { bahçe } \\ \text { ağla- } & \text { an (zaman) } & \text { arkadaşol- } & \text { ayak } & \text { bak- } \\ \text { aile } & \text { anla- } & \text { arkadaşlık } & \text { ayakkabı } & \text { balık } \\ \text { ak- } & \text { anlat- } & \text { artık } & \text { ayı } & \text { balkon }\end{array}$




\begin{tabular}{|c|c|c|c|c|}
\hline bardak & çabuk & döv- & göre & ilgili \\
\hline baş & çağır- & dünya & görebil- & ilk \\
\hline bas- & çal- & dur- & görün- & ilk önce \\
\hline başka & çalış- & durum & göster- & in- \\
\hline başla- & cam & düş & götür- & inan- \\
\hline bat- & can & düşün- & göz & indir- \\
\hline bayram & çanta & duvar & gül & inek \\
\hline bazen & çarp- & duy- & gül- & insan \\
\hline bazı & çek- & düzenle- & gün & ip \\
\hline bebek & cennet & edin- & güneş & is \\
\hline beğen- & cevap & eğer & güven- & ışık \\
\hline bekle- & çık- & eğlen- & güzel & isim \\
\hline belki & çıkar- & eğlenceli & hadi & iste \\
\hline ben (zamir) & çıkart- & el (organ) & hala (henüz) & iste- \\
\hline bence & çiçek & elbise & hangi & iyi \\
\hline benze- & civciv & emek & hasta & izle- \\
\hline beraber & çiz- & en (zarf) & hastalan- & kaç- \\
\hline beri & çizgi film & erkek & hastane & kadar \\
\hline besle- & çoban & erken & hatırla- & kafa \\
\hline beyaz & çocuk & eski & hatta & kafes \\
\hline bil- & çok & eskiden & hava & kahvaltı \\
\hline bile & çöp & eşya & havuç & kal- \\
\hline bilgisayar & çünkü & et- & havuz & kaldır- \\
\hline bin- & da (de) & ev & hayal & kalk- \\
\hline bir & daha & evcilik & hayır(xevet) & kalp \\
\hline bir kere & dakika & evet & hayvan & kalpli \\
\hline bir sürü & davran- & farklı & hayvanat bahçesi & kapat- \\
\hline bir tane & davranış & fazla & hazırla- & kapı \\
\hline bırak- & de- & fikir & hediye & kaplumbağa \\
\hline biraz & dede & film & hem & karanlık \\
\hline birbiri & değil & firçala- & hemen & karar \\
\hline birçok & değişik & geç- & hep & kardeş \\
\hline biri & değiştir- & gece & her & karın \\
\hline birkaç & deli & geçin- & her gün & karşı \\
\hline birlikte & deniz & geçir- & her zaman & kavga et- \\
\hline bisiklet & dev & gel- & herkes & kay- \\
\hline bit- (tüken-) & devam et- & gene & hiç & kaybet- \\
\hline bitir- & diğer & gerçek & hiç kimse & kaybol- \\
\hline biz & dinle- & gerek- & hiçbir & kazan- \\
\hline boş & diş & geri & hikâye & kedi \\
\hline boy (uzunluk) & dışarı & getir- & hisset- & kenar \\
\hline böyle & doğ- & gez- & hızlı & kendi \\
\hline böylece & doğa & gibi & iç & kere \\
\hline bu & doğru & gidebil- & iç- & kes- \\
\hline bugün & doğum günü & gir- & içeri & kesil- \\
\hline bul- & doktor & git- & için & keşke \\
\hline bulaşık & dolaş- & giy- & ihtiyaç & kez \\
\hline bura & dolu (boş) & giyin- & ilaç & kim \\
\hline bütün & don- & gol & ile & kimse \\
\hline büyü- & dondurma & gönder- & ileri & kır- \\
\hline büyük & dost & gör- & ilgilen- & kırıl- \\
\hline
\end{tabular}




\begin{tabular}{|c|c|c|c|c|}
\hline kırmızı & neden & sadece & tam & ya da \\
\hline kısa & nere & sağ (yon) & tamam & yağ- \\
\hline kişi & neyse & sağla- & tane & yağmur \\
\hline kitap & niye & sakla- & tanı- & yak- (ateş) \\
\hline kıyafet & 0 & saklambaç & tanış- & yakala- \\
\hline kız & öbür & saklan- & taraf & yakın \\
\hline kız- & oda & salıncak & taş & yaklaş- \\
\hline kocaman & ödev & sallan- & taşı- & yalan \\
\hline kol & odun & san- & tatlı & yan \\
\hline komik & oğlan & sanki & tavşan & yan- \\
\hline komşu & öğrenci & sarı & tek & yani \\
\hline konu & öğretmen & sarıl- & tekrar & yanlış \\
\hline konuş- & oku- & şarkı & telefon & yap- \\
\hline köpek & okul & sat- & televizyon & yapabil- \\
\hline körebe & ol- & say- & temiz & yaramaz \\
\hline kork- & olabil- & sebze & temizle- & yardım \\
\hline koş-(koşu) & oldur- & seç- & temizlik & yardım et- \\
\hline kötü & on & şeker & tepe & yaş (ömür) \\
\hline kötülük & önce & sen & teşekkür et- & yaşa- \\
\hline kovala- & önceden & ses & teyze & yat- \\
\hline koy & öp- & sev- & tilki & yatak \\
\hline koy- & ora & sevin- & top & yavru \\
\hline küçük & orta & şey & topla- & yazı (nesir) \\
\hline kulak & otobüs & sil- & toplan- & yem \\
\hline kullan- & otur- & silah & toprak & yemek \\
\hline kurbağa & öyle & simdi & tren & yeni \\
\hline kurtar- & oyna- & sinirlen- & tüm & yer \\
\hline kus- & oyun & siyah & tut- & yeşil \\
\hline kuş & oyuncak & siz & uç- & yet- \\
\hline kuzen & özle- & sofra & uçak & yıka- \\
\hline leylek & para & soğuk & ulaş- & yine \\
\hline maç & parça & son & unut- & yiyecek \\
\hline malzeme & park & sonra & üst & yok \\
\hline masa & paylaş- & sor- & uyan- & yol \\
\hline masal & pazar & soru & uyu- & yukarı \\
\hline mavi & pek & şöyle & uzak & yüksek \\
\hline merak et- & peri & söyle- & üzgün & yürü- \\
\hline merdiven & pes & söz & üzül- & yüz (çehre) \\
\hline mesela & piknik & spor & uzun & yüz-(suda) \\
\hline meyve & piknik yap- & su & üzüntü & zaman \\
\hline motor & pişir- & şu & var & zaten \\
\hline mutfak & polis & sür- & ve & zıpla- \\
\hline mutlu & renk & sürekli & ver- & zor \\
\hline mutlu ol- & resim & tabak & veya & \\
\hline mutluluk & saat & tabii (elbette) & vur- & \\
\hline nasıl & sabah & tak- & ya (bağlaç) & \\
\hline ne & saç & takıl- & ya (ünlem) & \\
\hline
\end{tabular}


Okul Öncesi Çocuklarının Ilk 1000 Kelimesi ile Çocuk Kitaplarındaki (Baş, 2006) ilk 1000 Kelimenin Karşılaştırılmasına Yönelik Bulgular

Okul öncesi çocuklarının kullandığı ilk 1000 kelime ile çocuk kitaplarındaki ilk 1000 kelime birleştirildiğinde ortaya çıkan listedeki birbirinden farklı kelimelerin sayısı 1499'dur. Her iki listede de yer alan ortak kelimelerin sayısı $475^{\prime}$ tir. İki sıklık listesinde $\% 47,5$ oranında uyum olduğu görülmektedir. íki liste birbirinden \%52,5 oranında farklılaşmaktadır.

îki listede ortak olan 475 kelime alfabetik olarak aşağıda verilmiştir.

Tablo 6.

Ortak Kelimeler Listesi

\begin{tabular}{|c|c|c|c|c|}
\hline Ali & aslında & bin & çarp- & dol- \\
\hline Allah & at & bin- & çek- & dolaş- \\
\hline İstanbul & at- & bir & cennet & dolu (xboş) \\
\hline abla & ateş & bir an & cevap & dön- \\
\hline aç- & atla- & bir daha & çevir- & dört \\
\hline açık & ayak & bırak- & çık- & dost \\
\hline acil- & ayı & biraz & çıkar- & döv- \\
\hline adam & ayır- & birbiri & çiçek & doy- \\
\hline ağabey & ayni & biri & çoban & dua \\
\hline ağaç & ayrıl- & birkaç & çocuk & dünya \\
\hline ağır & $\mathrm{az}$ & birlikte & çok & dur- \\
\hline ağız & baba & bit- (tüken-) & çünkü & durum \\
\hline ağla- & bacak & bitir- & da (de) & düş \\
\hline aile & bahçe & biz & daha & düşün- \\
\hline ak- & bak- & boş & damla & duvar \\
\hline akıl & balık & boy (uzunluk) & davran- & duy- \\
\hline akıllı & baş & böyle & de- & eğer \\
\hline akşam & bas- & böylece & dede & eğlen- \\
\hline al- & başka & bu & değil & el (organ) \\
\hline alt & başla- & bu kadar & değiştir- & elbise \\
\hline altı & bayram & bu yüzden & deli & en (zarf) \\
\hline altın & bazen & bugün & deniz & erkek \\
\hline ama & bazı & bul- & dev & eski \\
\hline amca & bebek & bulut & devam & et- \\
\hline an (zaman) & beğen- & bura & diğer & etek \\
\hline anla- & bekle- & burun & dil (organ) & ev \\
\hline anlat- & belki & bütün & dinle- & evet \\
\hline anne & belli (malum) & büyü- & dışarı & fazla \\
\hline anneanne & ben (zamir) & büyük & diş & geç- \\
\hline ara- & benze- & çabuk & diye & gece \\
\hline araba & beraber & çağır- & doğ- & geçir- \\
\hline arka & beri & çal- & doğru & gel- \\
\hline arkadaş & beş & çalış- & dök- & gene \\
\hline artık & beyaz & cam & doktor & gerçek \\
\hline as- & bil- & can & dökül- & gerek- \\
\hline aşağı & bile & canavar & dokun-(temas) & geri \\
\hline
\end{tabular}




\begin{tabular}{|c|c|c|c|c|}
\hline getir- & hey & karşı & kuş & pek \\
\hline gez- & hiç & kat- & kutu & peri \\
\hline gibi & hiç kimse & kavuş- & kuyruk & pes \\
\hline gir- & hiçbir & kaybet- & leylek & renk \\
\hline git- & hisset- & kaybol- & masa & resim \\
\hline giy- & hiz & kazan- & masal & saat \\
\hline gök & iç & kedi & mavi & sabah \\
\hline gökyüzü & iç- & kenar & meyve & saç \\
\hline gönder- & içeri & kendi & $\mathrm{mi} / \mathrm{mi} / \mathrm{mu} / \mathrm{mu}$ & sadece \\
\hline gör- & için & kendi kendine & mutfak & sağ (yön) \\
\hline göre & iki & kes- & mutlu & sakla- \\
\hline görün- & ilaç & kesil- & mutluluk & saklan- \\
\hline göster- & ile & kez & nasıl & saldır- \\
\hline götür- & ileri & ki & ne & san- \\
\hline göz & ilgili & kim & neden & sanki \\
\hline güçlü & ilk & kimse & nere & sarı \\
\hline gül & in- & kir- & niye & sarıl- \\
\hline gül- & inan- & kırıl- & 0 & şarkı \\
\hline gün & inek & kırmızı & o kadar & sat- \\
\hline gündüz & insan & kısa & obur & say- \\
\hline güneş & ip & kişi & oda & seç- \\
\hline güzel & iş & kitap & odun & sen \\
\hline hadi & ışık & kız & oğlan & ses \\
\hline hala (henüz) & isim & kız- & öğretmen & sev- \\
\hline halı & iste & kocaman & oku- & sevin- \\
\hline hangi & iste- & kol & okul & şey \\
\hline hani & iyi & kolay & ol- & sıkıl- \\
\hline hasta & izle- & koltuk & olabil- & silah \\
\hline hastalık & kaç- & komşu & öl- & şimdi \\
\hline hatırla- & kadar & konu & öldür- & siyah \\
\hline hatta & kafa & konuş- & ön & siz \\
\hline hava & kal- & kop- & önce & sofra \\
\hline hayır (xevet) & kaldır- & kopar- & öp- & soğuk \\
\hline hayvan & kalk- & köpek & ora & son \\
\hline hazırla- & kalp & kork- & orta & sonra \\
\hline hediye & kanat & koş- (koşu) & ortalık & sor- \\
\hline hem & kapat- & kötü & otur- & soru \\
\hline hemen & kapı & kötülük & öyle & şöyle \\
\hline hep & kara (renk) & köy & oyna- & söyle- \\
\hline hepsi & karanlık & koy- & oysa & söz \\
\hline her & karar & kucak & oyun & su \\
\hline her gün & kardeş & küçük & para & sür- \\
\hline her zaman & karga & kulak & parça & şu \\
\hline herkes & karın & kurtar- & pazar & tak- \\
\hline
\end{tabular}




$\begin{array}{lllll}\text { takıl- } & \text { topla- } & \text { üç } & \text { yan- } & \text { yıldız } \\ \text { tam } & \text { toplan- } & \text { üzüntü } & \text { yani } & \text { yine } \\ \text { tamam } & \text { toprak } & \text { var } & \text { yap- } & \text { yiyecek } \\ \text { tane } & \text { tüm } & \text { ve } & \text { yaprak } & \text { yok } \\ \text { tanı- } & \text { tut- } & \text { ver- } & \text { yardım } & \text { yoksa } \\ \text { taraf } & \text { uç- } & \text { vücut } & \text { yaş (ömür) } & \text { yol } \\ \text { taş } & \text { ulaş- } & \text { vur- } & \text { yaşa- } & \text { yorgun } \\ \text { taşı- } & \text { unut- } & \text { ya (bağlaç) } & \text { yat- } & \text { yukarı } \\ \text { tatlı } & \text { üst } & \text { ya da } & \text { yatak } & \text { yüksek } \\ \text { tek } & \text { uyan- } & \text { yağ- } & \text { yavru } & \text { yürü- } \\ \text { tekrar } & \text { uyu- } & \text { yağmur } & \text { ye- } & \text { yüz (çehre) } \\ \text { temiz } & \text { uzak } & \text { yak- (ateş) } & \text { yeni } & \text { yüz- (suda) } \\ \text { tepe } & \text { uzan- } & \text { yakala- } & \text { yer } & \text { zaman } \\ \text { teyze } & \text { uzat- } & \text { yakın } & \text { yeşil } & \text { zaten } \\ \text { tilki } & \text { uzay } & \text { yaklaş- } & \text { yet- } & \text { zor } \\ \text { titre- } & \text { üzül- } & \text { yalan } & \text { yetiş- } & \\ \text { top } & \text { uzun } & \text { yan } & \text { yıka- } & \end{array}$

Okul Öncesi Çocuklarının IIlk 1000 Kelimesi ile 1. Sınıf Türkçe Ders Kitabındaki Ilk 1000 Kelimenin Karşılaştırılmasına Yönelik Bulgular

Okul öncesi çocuklarının kullandığı ilk 1000 kelime ile 1. Sınıf Türkçe ders kitabındaki ilk 1000 kelime birleştirildiğinde ortaya çıkan listedeki birbirinden farklı kelimelerin sayısı 1552'dir. Her iki listede de yer alan ortak kelimelerin sayısı 378'dir. Iki sıklık listesinde $\% 37,8$ oranında uyum olduğu görülmektedir. İki liste birbirinden \%62,2 oranında farklılaşmaktadır.

iki listede ortak olan 378 kelime alfabetik olarak aşağıda verilmiştir.

Tablo 7.

Ortak Kelimeler Listesi

$\begin{array}{lllll}\text { aç- } & \text { as- } & \text { banyo } & \text { beyaz } & \text { boya } \\ \text { adam } & \text { aşağı } & \text { bas } & \text { bil- } & \text { boya- } \\ \text { ağaç } & \text { at } & \text { bas- } & \text { bile } & \text { böyle } \\ \text { ağır } & \text { at- } & \text { basit } & \text { bilgisayar } & \text { böylece } \\ \text { ağla- } & \text { atla- } & \text { başka } & \text { bin } & \text { bu } \\ \text { aile } & \text { ay (uydu) } & \text { basla- } & \text { bin- } & \text { bugün } \\ \text { akıllı } & \text { ayak } & \text { bat- } & \text { bir } & \text { bul- } \\ \text { al- } & \text { aydınlat- } & \text { baykuş } & \text { bırak- } & \text { bulut } \\ \text { alt } & \text { aynı } & \text { bayram } & \text { biraz } & \text { bura } \\ \text { altı } & \text { ayrıca } & \text { bazen } & \text { birbiri } & \text { bütün } \\ \text { ama } & \text { ayrıl- } & \text { bazı } & \text { biri } & \text { büyü- } \\ \text { anla- } & \text { az } & \text { bekle- } & \text { birikinti } & \text { büyük } \\ \text { anlat- } & \text { baba } & \text { belki } & \text { birkaç } & \text { çabuk } \\ \text { anne } & \text { babaanne } & \text { ben (zamir) } & \text { bisiklet } & \text { çalış- } \\ \text { ara- } & \text { bahçe } & \text { bence } & \text { bit- (tüken-) } & \text { can } \\ \text { arka } & \text { bak- } & \text { benze- } & \text { biz } & \text { çarp- } \\ \text { arkadaş } & \text { balık } & \text { beraber } & \text { böcek } & \text { çek- } \\ \text { artık } & \text { balon } & \text { beş } & \text { boy } & \text { çekmece } \\ & & & \text { (uzunluk) } & \end{array}$




\begin{tabular}{|c|c|c|c|c|}
\hline cennet & erken & hemen & kaybol- & nere \\
\hline çevir- & eski & hep & kazan- & niye \\
\hline çık- & et- & hepsi & kedi & 0 \\
\hline çıkabil- & etkinlik & her & kenar & oğlan \\
\hline civciv & ev & herkes & kendi & oku- \\
\hline çiçek & evet & hey & kere & ol- \\
\hline çiz- & falan & hiç & kesil- & olabil- \\
\hline çocuk & fazla & hiçbir & kesin & önce \\
\hline çok & fikir & hızlı & keşke & ora \\
\hline çünkü & fil & i- & kez & otur- \\
\hline da (de) & film & iç- & ki & ön \\
\hline daha & geç- & içeri & kim & öyle \\
\hline de- & gece & için & kimse & oyna- \\
\hline dede & gel- & iki & kırıl- & oyun \\
\hline değil & gerçek & ile & kirpi & parlak \\
\hline değiştir- & gerek- & ilgili & kısa & pek \\
\hline deniz & geri & ilk & kişi & pes \\
\hline dev & getir- & in- & kitap & renk \\
\hline devam & gibi & inan- & kıvırcık & renkli \\
\hline diğer & gir- & insan & kIz & resim \\
\hline diken & git- & ip & kız- & roket \\
\hline dinle- & gök & is & kol & rüzgâr \\
\hline diş & gökyüzü & ışık & kolay & sabah \\
\hline diye & gol & isim & komik & sadece \\
\hline doğ- & gör- & iste & konuş- & saklan- \\
\hline doğru & göre & iste- & köpek & san- \\
\hline doğur- & görebil- & iyi & körebe & sanki \\
\hline dolaş- & göster- & kaç- & kork- & sarıl- \\
\hline dön- & götür- & kadar & koş- (koşu) & su \\
\hline dört & göz & kafa & küçük & şarkı \\
\hline dost & gül- & kafes & kullan- & sebze \\
\hline doy- & gün & kâğıt & kurtar- & seç- \\
\hline dünya & gündüz & kal- & kuş & sen \\
\hline dur- & güneş & kaldır- & lazım & sert \\
\hline durum & güven- & kalk- & maç & ses \\
\hline düş & güzel & kalp & masal & sev- \\
\hline düşün- & hadi & kanat & mavi & sevin- \\
\hline duvar & hangi & kapat- & meyve & şey \\
\hline duy- & hatırla- & kara (renk) & $\mathrm{mi} / \mathrm{mi} / \mathrm{mu} / \mathrm{mu}$ & simdi \\
\hline düz & hava & kardeş & misafir & siz \\
\hline eğer & havuç & karga & mutlu & son \\
\hline eğlen- & hayvan & karınca & mutluluk & sonra \\
\hline eğlenceli & hazırla- & karşı & nasıl & sor- \\
\hline el (organ) & hem & kat & ne & şöyle \\
\hline
\end{tabular}




$\begin{array}{lllll}\text { söyle- } & \text { tepe } & \text { uyut- } & \text { yap- } & \text { yemek } \\ \text { söz } & \text { teyze } & \text { uzak } & \text { yapabil- } & \text { yeni } \\ \text { sür- } & \text { tilki } & \text { uzay } & \text { yapıştır- } & \text { yer } \\ \text { sürekli } & \text { top } & \text { üzül- } & \text { yaprak } & \text { yet- } \\ \text { tabii (elbette) } & \text { toplan- } & \text { uzun } & \text { yaramaz } & \text { yıldız } \\ \text { tam } & \text { toprak } & \text { var } & \text { yaş (ömür) } & \text { yine } \\ \text { tane } & \text { tüm } & \text { ve } & \text { yaşa- } & \text { yok } \\ \text { taraf } & \text { tut- } & \text { ver- } & \text { yastık } & \text { yol } \\ \text { tas } & \text { üç } & \text { vur- } & \text { yat- } & \text { yorgun } \\ \text { tatlı } & \text { uç- } & \text { yağmur } & \text { yatak } & \text { yukarı } \\ \text { tavşan } & \text { unut- } & \text { yak-(ateş) } & \text { yavru } & \text { yüksek } \\ \text { tek } & \text { üst } & \text { yakın } & \text { yazı (nesir) } & \text { yürü- } \\ \text { telefon } & \text { uyan- } & \text { yaklaş- } & \text { ye- } & \text { zaman } \\ \text { televizyon } & \text { uyu- } & \text { yan } & \text { yem } & \text { zürafa }\end{array}$

Okul Öncesi Çocuklarının ilk 1000 Kelimesi ile ilkokul Öğrencilerinin ilk 1000 Kelimesinin Karşılaştırılmasına Yönelik Bulgular

Okul öncesi çocuklarının kullandığı ilk 1000 kelime ile ilkokul öğrencilerinin ilk 1000 kelimesi birleştirildiğinde ortaya çıkan listedeki birbirinden farklı kelimelerin sayısı 1528'dir. Her iki listede de yer alan ortak kelimelerin sayısı $455^{\prime}$ tir. İki sıklık listesinde $\% 45,5$ oranında uyum olduğu görülmektedir. iki liste birbirinden $\% 54,5$ oranında farklılaşmaktadır.

İki listede ortak olan 455 kelime alfabetik olarak aşağıda verilmiştir.

Tablo 8.

Ortak Kelimeler Listesi

$\begin{array}{lllll}\text { abla } & \text { anne } & \text { az } & \text { bekle- } & \text { birkaç } \\ \text { aç- } & \text { anneanne } & \text { azıcık } & \text { ben (zamir) } & \text { birlikte } \\ \text { adam } & \text { apartman } & \text { baba } & \text { bence } & \text { bisiklet } \\ \text { ağabey } & \text { ara- } & \text { babaanne } & \text { benze- } & \text { bit- (tüken-) } \\ \text { ağaç } & \text { araba } & \text { bacak } & \text { beraber } & \text { bitir- } \\ \text { ağız } & \text { arka } & \text { bahçe } & \text { beri } & \text { biz } \\ \text { ağla- } & \text { arkadaş } & \text { bak- } & \text { beş } & \text { boy (uzunluk) } \\ \text { aile } & \text { artık } & \text { bal } & \text { besle- } & \text { boya } \\ \text { akıl } & \text { as- } & \text { balık } & \text { beyaz } & \text { böyle } \\ \text { akıllı } & \text { aşağı } & \text { banyo } & \text { bıçak } & \text { böylece } \\ \text { akşam } & \text { at } & \text { bardak } & \text { bil- } & \text { bozul- } \\ \text { al- } & \text { at- } & \text { bas } & \text { bilgisayar } & \text { bu } \\ \text { alabil- } & \text { ateş } & \text { bas- } & \text { bin- } & \text { bugün } \\ \text { alt } & \text { atla- } & \text { başka } & \text { bir } & \text { bul- } \\ \text { altı } & \text { ayak } & \text { başla- } & \text { bir sürü } & \text { bulaşık } \\ \text { altın } & \text { ayakkabı } & \text { bayram } & \text { bir tane } & \text { bura } \\ \text { ama } & \text { ayı } & \text { bazen } & \text { bırak- } & \text { burun } \\ \text { amca } & \text { ayır- } & \text { bazı } & \text { biraz } & \text { bütün } \\ \text { anla- } & \text { aynı } & \text { bebek } & \text { birazcık } & \text { büyü- } \\ \text { anlat- } & \text { ayrıca } & \text { beğen- } & \text { birbiri } & \text { büyük } \\ \text { anlatabil- } & \text { ayrı- } & \text { bekçi } & \text { biri } & \text { çabuk } \\ & & & & \end{array}$




\begin{tabular}{|c|c|c|c|c|}
\hline cadı & durum & gündüz & izle- & konu \\
\hline çağır- & düş & güneş & kabuk & konuş- \\
\hline çal- & düşün- & güzel & kaç- & köpek \\
\hline çalış- & duvar & hadi & kadar & körebe \\
\hline çamaşır & duy- & halı & kahvaltı & kork- \\
\hline can & düz & hangi & kal- & koş- (koşu) \\
\hline çanta & eğer & hasta & kaldır- & kotu \\
\hline çek- & eğlen- & hastalan- & kalk- & kovala- \\
\hline çekmece & eğlenceli & hava & kanat & koy \\
\hline çiçek & el (organ) & havuç & kap- & koy- \\
\hline çık- & elbise & havuz & kapalı & kucak \\
\hline çıkar- & en (zarf) & hayvan & kapat- & küçük \\
\hline çıkart- & erkek & hayvanat bahçesi & kapı & kulak \\
\hline çimen & erken & hazırla- & kaplumbağa & kurbağa \\
\hline civciv & eski & hediye & kara (renk) & kuş \\
\hline çizgi film & eşya & hem & kardeş & kutu \\
\hline çoban & et- & hemen & karga & kuyruk \\
\hline çocuk & ev & hep & karşı & leylek \\
\hline çok & evcilik & her & katla- & maç \\
\hline çok çok & fazla & her gün & kavga et- & market \\
\hline çünkü & fil & herkes & kaybet- & masa \\
\hline da (de) & fırçala- & hiç & kaybol- & masal \\
\hline daha & geç- & hiçbir & kazan- & mavi \\
\hline de- & gece & hikâye & kedi & meyve \\
\hline dede & geçir- & hızlı & kelebek & $\mathrm{mi} / \mathrm{mi} / \mathrm{mu} / \mathrm{mu}$ \\
\hline değil & gel- & hoşlan- & kenar & mutlu \\
\hline değiştir- & gerek- & iç & kendi & mutlu ol- \\
\hline deniz & geri & iç- & kere & nasıl \\
\hline deri & getir- & için & kes- & ne \\
\hline devam et- & gez- & iğne & ki & neden \\
\hline diğer & gezme & iki & kim & nere \\
\hline dinozor & gibi & ile & kimse & 0 \\
\hline dinle- & gir- & ilk & kir- & öbür \\
\hline diş & git- & ilk önce & kirli & oda \\
\hline dışarı & giy- & in- & kırmızı & ödev \\
\hline diye & giyin- & indir- & kısa & odun \\
\hline doğru & gör- & inek & kişi & öğrenci \\
\hline doktor & göre & insan & kitap & öğretmen \\
\hline dolaş- & görün- & ip & kıyafet & oku- \\
\hline dön- & göster- & iş & $\mathrm{k} ı \mathrm{z}$ & okul \\
\hline dondurma & götür- & isim & kocaman & ol- \\
\hline dört & göz & iste & kok- & olabil- \\
\hline dünya & gül & iste- & kolay & ön \\
\hline dur- & gün & iyi & komşu & önce \\
\hline
\end{tabular}




$\begin{array}{lllll}\text { öp- } & \text { sakın } & \text { sor- } & \text { tırnak } & \text { yardım } \\ \text { ora } & \text { saklambaç } & \text { soru } & \text { top } & \text { yardım et- } \\ \text { örtü } & \text { saklan- } & \text { şöyle } & \text { topla- } & \text { yaş (ömür) } \\ \text { otobüs } & \text { salıncak } & \text { söyle- } & \text { tren } & \text { yaşa- } \\ \text { otur- } & \text { sallan- } & \text { söz } & \text { tut- } & \text { yat- } \\ \text { oturabil- } & \text { sandalye } & \text { su } & \text { üç } & \text { yatak } \\ \text { öyle } & \text { sanki } & \text { süpürge } & \text { uçak } & \text { yavru } \\ \text { oyna- } & \text { sarı } & \text { sür- } & \text { unut- } & \text { yazı (nesir) } \\ \text { oyun } & \text { şarkı } & \text { sürekli } & \text { üst } & \text { ye- } \\ \text { oyuncak } & \text { sat- } & \text { şu } & \text { uyan- } & \text { yemek } \\ \text { para } & \text { say- } & \text { tabak } & \text { uyu- } & \text { yer } \\ \text { parça } & \text { sebze } & \text { tabii (elbette) } & \text { uzak } & \text { yeşil } \\ \text { park } & \text { seç- } & \text { tane } & \text { üzgün } & \text { yıka- } \\ \text { pazar } & \text { sen } & \text { taraf } & \text { üzül- } & \text { yine } \\ \text { pes } & \text { ses } & \text { taş } & \text { uzun } & \text { yiyecek } \\ \text { piknik } & \text { sev- } & \text { taşı- } & \text { var } & \text { yok } \\ \text { pis } & \text { sevin- } & \text { tatlı } & \text { ve } & \text { yol } \\ \text { pişir- } & \text { şey } & \text { tavşan } & \text { ver- } & \text { yüksek } \\ \text { reklam } & \text { sıkıl- } & \text { tek } & \text { veya } & \text { yürü- } \\ \text { renk } & \text { sil- } & \text { tekrar } & \text { ya da } & \text { yuvarlak } \\ \text { renkli } & \text { şimdi } & \text { telefon } & \text { yakala- } & \text { yüz (cehre) } \\ \text { resim } & \text { şirin } & \text { televizyon } & \text { yaklaş- } & \text { yüz- (suda) } \\ \text { saat } & \text { siyah } & \text { temiz } & \text { yan } & \text { zaman } \\ \text { sabah } & \text { siz } & \text { temizle- } & \text { yan- } & \text { zıpla- } \\ \text { saç } & \text { sofra } & \text { temizlik } & \text { yani } & \text { zor } \\ \text { sadece } & \text { son } & \text { teşekkür et- } & \text { yap- } & \text { zürafa } \\ \text { sağ (yon) } & \text { sonra } & \text { teyze } & \text { yaramaz } & \\ & & & & \end{array}$

\section{Tartışma ve Sonuç}

60 ay ve üzeri okul öncesi çocuklarının sözlü dil örneği üzerinden kelime hazinesinin tespit edilip sıklık listesinin derlem temelli çeşitli listelerle karşılaştırıldığı bu çalışmada ulaşılan sonuçlar şöyledir:

Okul öncesi çocuklarının etkileşimli okuma yapılarak elde edilen sözlü verilere göre kullandıkları toplam kelime sayısı 21.299, birbirinden farklı kelime sayısı ise 1732'dir. Çocuklar konuşmalarında her farklı kelimeyi ortalama olarak 12,29 kez tekrar etmiştir. Acarlar (2005) çocukların kullandığı toplam sözcük sayısının artmasıyla sözcük tekrarlarının da arttığını belirtmektedir. Çocuklar kelime türü olarak en fazla isimleri kullanmıştır. Bu isimler çocuğun hem gündelik hayatında en fazla ilişkili olduğu kavramlarla hem de zengin hayal dünyalarındaki kavramlarla ilgilidir. Gelişim düzeylerine göre çocuklar, bu dönemlerinde dil bilgisi kurallarını içselleştirdiği için bütün kelime türlerini rahatlıkla kullanmaktadırlar. Konuşurken sebep-sonuç, amaç-sonuç ilişkisi kurdukları, olaylar ve karakterler arasında ilişki kurabildikleri, artan meraklarıyla birlikte sorgulamalar yaptıkları için en sık kullanılan ilk 100 kelimeyi türleri bakımından zengin kullandıkları tespit edilmiştir.

Okul öncesi çocuklarının ilk 1000 kelimesi ile Aksan ve arkadaşlarının (2017) A Frequency Dictionary of Turkish (Türkçe Sıklık Sözlüğü) adlı çalışmalarındaki ilk 1000 kelime karşılaştırıldığında iki listenin \%25,4 oranında uyumluyken $\% 74,6$ oranında farklılaştığı tespit edilmiştir. TSS dilin genel görünümünü ortaya koyan bir derlem olduğu ve soyut kelime fazla barındırdığı ve bu da çocukların 
gelişim özelliklerine aykırı olduğu için (Karadağ, 2019a) iki liste arasındaki uyum oranının az olması beklenen bir durumdur.

Okul öncesi çocuklarının ilk 1000 kelimesi ile Karadağ’ın (2019b) temel eğitim düzeyindeki öğrencilerin yazılı anlatımlarından oluşturulan sıklık listesi olan "Hedef Kelime Listesi"ndeki ilk 1000 kelime karşılaştırıldığında iki listenin $\% 53,6$ oranında uyumlu olduğu, $\% 46,4$ oranında ise farklılaştığı tespit edilmiştir.

Okul öncesi çocuklarının ilk 1000 kelimesi ile çocuk kitaplarındaki ilk 1000 kelime karşılaştııılı̆̆ında iki listenin \%47,5 oranında uyumlu, \%52,5 oranında ise farklı olduğu tespit edilmiştir. İlköğretim öğrencilerinin sıklık listesi ile çocuk kitaplarının sıklık listesini karşılaştıran Baş (2006) \%63 oranında iki listenin uyumlu olduğunu tespit etmiştir. Baş'ın (2006) araştırmasında uyum oranının daha yüksek olmasında temel etken, araştırmanın ilköğretimin çeşitli seviyelerindeki eserleri içermesidir.

Okul öncesi çocuklarının ilk 1000 kelimesi ile 1. sınıf Türkçe ders kitabındaki ilk 1000 kelime karşılaştıııldığında iki listede $\% 37,8$ oranında ortaklık olduğu, \%62,2 oranında ise farklılaşma olduğu görülmektedir. Dil edinme sürecinde olan çocukların diliyle kitap dilleri arasında elbette farklılık olacaktır ancak bu farklılı̆ın ders kitaplarında çocuk kitaplarının da üstünde olması dikkat çekicidir.

Okul öncesi çocuklarının ilk 1000 kelimesi ile ilkokul öğrencilerinin ilk 1000 kelimesi karşılaştırıldığında ise iki listenin $\% 45,5$ oranında uyumlu olduğu, $\% 54,5$ oranında farklılaştığı tespit edilmiştir.

Listelerin karşılaştırma sonuçlarına göre çocukların ilk 1000 kelimesi ile Türkçe Sıklık Sözlüğü ve 1. Sınıf Türkçe Ders Kitabı arasında ortaklığın daha az, dil edinme sürecindeki çocukların gelişim düzeyi göz önüne alındığında çocukların ilk 1000 kelimesi ile Hedef Kelime Listesi, çocuk kitapları ve ilkokul öğrencilerinin ilk 1000 kelimesinin daha yüksek oranda örtüştüğü söylenebilir. Buna rağmen 60 ay ve üzeri okul öncesi çocuklarının kelime sıklık listesi ile diğer tüm derlemlerin kelime sıklık listelerinin yarıdan fazla örtüşmediği görülmektedir. Uyumlu olan kelimelerin içinde de hemen hemen her seviyede kullanılan iletişimsel kelimeler yer almaktadır. Bu iletişimsel kelimeler göz önüne alındığında listelerin ileri sıralarında farklılığın daha da arttığı görülmektedir.

Genel dil derlemleri dilin sıklık bakımından genel görünümünü ortaya koymakta ve öğrencilerin eğitimi için lise öncesi seviyelerde işlevsel olmamaktadır. Bu yüzden okul öncesi, ortaokul ve lise eğitim seviyelerinde hazırlanan özel derlemler eğitimin düzenlenmesinde önem taşımaktadır. Bu özel derlemler çocuk kitapları ve ders kitaplarındaki metinlerin nitelik ve seviyesinin belirlenmesinde, çocuklara öğretilecek kelimelere referans olması bakımından önemlidir. Bu çalışmanın sonucuna göre okul öncesi çocuklarının ilk 1000 kelimesi ile diğer derlemlerin ilk 1000 kelimesinin yarıdan fazla örtüşmemesi durumu bu çalışmada incelenen derlemlerin okul öncesi çocukları için referans olarak kullanılamayacağını göstermektedir. Bunun için daha kapsamlı çalışmalarla okul öncesi çocuklarının sözlü dilleri üzerinden hazırlanacak işlevsel ve büyük derlemlerin ana dil eğitiminde referans olarak kullanılması gerektiği ortaya çıkmaktadır. Bu sonuç Karadağ'ın (2019a) ana dili olarak Türkçe eğitimi bakımından geniş hacimli bir özel çocuk dili derlemine ihtiyaç duyulduğunu ortaya koyan çalışması ile örtüşmektedir. Ayrıca okul öncesinde dönemde dil ve zihin gelişimi hızlı olduğu ve uyaran sayısı her geçen gün arttığı için hazırlanacak derlemlerin belli aralıklarla güncellenmesi gerekmektedir.

\section{Araştırma ve Yayın Etiği}

Bu çalışmada "Yükseköğretim Kurumları Bilimsel Araştırma ve Yayın Etiği Yönergesi" kapsamında uyulması belirtilen tüm kurallara uyulmuştur. Yönergenin ikinci bölümü olan "Bilimsel Araştırma ve Yayın Etiğine Aykırı Eylemler" başlığı altında belirtilen eylemlerden hiçbiri gerçekleştirilmemiştir.

\section{Etik Kurul izni}

Kurul adı = Erzincan III Milli Eğitim Müdürlüğü

Karar tarihi $=18.10 .2017$ 
Belge sayı numarası $=77629021-44-E \cdot 16967303$

\section{Yazarların Katkı Oranı}

Bu makale, yazarın kendisi tarafından tek başına hazırlanmıştır.

\section{Çıkar Çatışması}

Çıkar çatışması teşkil edebilecek durumlar ve ilişkiler yoktur.

\section{Kaynaklar}

Acarlar, F. (2005). Türkçe ediniminde gelişimsel özelliklerin dil örneği ölçümleri açısından incelenmesi. Türk Psikoloji Dergisi, 20(56), 61-74

Aktürk, B. (2012). Understanding the Gestural, Lexical and Grammatical Development of TurkishSpeaking Infants and Toddlers: Validity Study of the Turkish Communicative Development Inventory (TIGE) (Yayımlanmamış yüksek lisans tezi). Hacettepe Üniversitesi Sağlık Bilimleri Enstitüsü, Ankara.

Aksan, D. (2000). Her yönüyle dil ana çizgileriyle dilbilim. Ankara: TDK Yayınları.

Aksan, Y., Aksan, M., Mersinli, Ü. \& Demirhan, U.U. (2017). A frequency dictionary of Turkish. London and New York: Routledge.

Altun, D. (2019). 60-71 aylık okul öncesi dönemdeki çocukların alıcı ve ifade edici dil kelime bilgisinin teknoloji kullanımı ve ailesel faktörlere göre incelenmesi. Uluslararası Türkçe Edebiyat Kültür Eğitim Dergisi, 8(2), 1158-1182.

Aydoğan, Y. ve Koçak, N. (2003). Okul öncesi çocukların dil gelişimlerine etki eden faktörlerin incelenmesi. Milli Ĕgitim Dergisi, 159, 203-210.

Ayrancı, B. B. (2018). 0-12 yaş dil gelişimi uygulamaları ve yapılması gerekenler. Kırıkkale Üniversitesi Sosyal Bilimler Dergisi, 8(1), 13-34.

Baş, B. (2006). 1985-2005 yılları arasında çocuk edebiyatı sahasında yazılmış tahkiyeli metinlerin söz varlığı üzerine bir araştırma (Yayımlanmamış doktora tezi). Gazi Üniversitesi, Eğitim Bilimleri Enstitüsü, Ankara.

Creswell, J. W. (2013). Nitel araştırma yöntemleri: Beş yaklaşıma göre nitel araştırma ve araştırma deseni. Ankara: Siyasal Kitabevi.

Dereli, E. (2003). Okul öncesi eğitime devam eden 4-6 yaş arasındaki çocukların ifade edici dil düzeylerinin incelenmesi (Konya ili örneği) (Yayımlanmamış yüksek lisans tezi). Selçuk Üniversitesi Sosyal Bilimler Enstitüsü, Ankara.

Dereli, E., Koçak, N. (2005). Okul öncesi eğitime devam eden 4-6 yaş arasındaki çocukların ifade edici dil düzeylerinin bakım tarzı ve anne- baba eğitim düzeyi açısından incelenmesi Konya ili örneği. Selçuk Üniversitesi Sosyal Bilimler Enstitüsü Dergisi , (14) , 245-253 .

Derman, M.T. (2017). 4-6 yaş çocukların sözcük dağarcıklarının ailesel faktörlere göre incelenmesi. Abant İzzet Baysal Üniversitesi Eğitim Fakültesi Dergisi, 17 (1), 372-383.

Erdoğan, S., Bekir, H.Ş ve Aras. S.E. (2005). Alt sosyoekonomik bölgelerde ana sınıfına devam eden 5-6 yaş grubundaki çocukların dil gelişim düzeylerine bazı faktörlerin etkisinin incelenmesi. Çukurova Üniversitesi Sosyal Bilimler Enstitüsü Dergisi, 14(1), 231-246.

Ergin, B. (2012) 5-6 yaş çocuklarının dil gelişim düzeyleri ile sosyal kabul durumları arasındaki ilişkinin incelenmesi (Yayımlanmamış yüksek lisans tezi). Selçuk Üniversitesi Sosyal Bilimler Enstitüsü, Konya.

Eryılmaz D., Uladı G., Geyik M. ve Öztürk M. (2019). 36-72 aylık çocukların dil gelişim özelliklerinin çeşitli değişkenler bakımından incelenmesi. Karabük Üniversitesi Sosyal Bilimler Enstitüsü Dergisi. 9(1), 265-277.

Güneş, F. (2010). Ninnilerin çocukların dil ve zihinsel gelişimine etkisi. ZfWT Zeitschrift für die Welt der Türken, Journal of World of Turks. 2(3), 27-38.

Işıtan, S. ve Turan, F. (2014). Çocuklarda dil gelişiminin değerlendirilmesinde bir anlatı analizi yaklaşımı olarak öykü anlatımı. Eğitim Bilimleri ve Uygulama. 13 (25), 105-124 
Karacan, E. (2000a). Bebeklerde ve çocuklarda dil gelişimi. Klinik Psikiyatri, 3(4), 263-268.

Karacan, E. (2000b). Çocuklarda dil gelişimini etkileyen faktörler. Sürekli Tıp Eğitimi Dergisi, 9(7).

Karadağ, Ö. (2005). Illköğretim I. kademe öğrencilerinin kelime hazinesi üzerine bir araştırma (Yayımlanmamış doktora tezi). Gazi Üniversitesi Eğitim Bilimleri Enstitüsü, Ankara.

Karadağ, Ö. (2019a). Neden bir çocuk dili derlemine ihtiyacımız var? Ana Dili Eğitimi Dergisi, 7(3), 765780.

Karadağ, Ö. (2019b). Kelime öğretimi. Ankara: Pegem Akademi.

Koçak, N., Ergin, B. ve Yalçın, H. (2014). 60-72 aylık çocukların Türkçe dil kullanımı düzeyleri ve etki eden faktörlerin incelenmesi. Karamanoğlu Mehmetbey Üniversitesi Sosyal ve Ekonomik Araştırmalar Dergisi, 2014(4), 100-106.

Özbaydar, B. (1970). 12-24 ay arasında dil gelişmesi. İstanbul Üniversitesi Tecrubi Psikoloji Çalışmaları, 8, 79-86.

Savaş, M. ve Turan, M. (2011). Okulöncesi altı yaş grubu öğrencilerin sahip oldukları kelime servetinin incelenmesi. New World Science Academy (NWWSA). 6(1), 841-859.

Yapıcı, Ş. (2004). Çocukta dil gelişimi. Uluslararası Insan Bilimleri Dergisi, 1(1), 1-18.

Yıldırım, A. (2008). Okul öncesi eğitim kurumlarından yararlanmayan 4-5 yaş çocuklarının dil gelişsimini etkileyen faktörlerin incelenmesi (Konya ili örneği) (Yayımlanmamış yüksek lisans tezi). Selçuk Üniversitesi Sosyal Bilimler Enstitüsü, Konya.

Zevenbergen, A. A. \& Whitehurst, G. J. (2003). Dialogic reading: a shared book reading intervention for preschoolers. on reading books to children: parents and teachers. (eds) Anne van Kleeck, Steven A. Stahl, \& Eurydice B. Bauer London: Lawrance Erlbaum.

\section{Extended Abstract}

\section{Introduction}

Body, language, and mind development progresses very rapidly between 0-6 ages. Developments in this period determine the child's life and future (Güneş, 2010, p. 28). Language develops rapidly in the pre-school period, supporting this development process helps both social and mental development in the child (Ayranci, 2018, p.17). The acquisition of language is directly based on the cognitive development of the child, and each of the mental adaptation processes is closely related to perception, concept development and language acquisition (Karacan, 2000b).

The concept development process, one of the important stages of language development, is related to age and experiences. In the cognitive development period, the concepts and words learned with the stimuli increase. Thus, the developing vocabulary supports the basic language skills. Vocabulary also plays an important role in the generation and development of ideas. In this process, the world of emotion and thought is enriched by the new words and concepts added to the receptive vocabulary in the mind and the relationships between them, and the new feelings and thoughts developed come into existence by being put into words. The expression of these words occurs through the selection of the most appropriate words in the productive vocabulary in the mind and the creation of linguistic codes according to the message to be conveyed by the feelings and thoughts.

Although it is assumed that the skillful use of the language and learning its subtleties occurs between the ages of 5-10, a significant part of the basic language acquisition process takes place at the age of 5-6 in the majority of children (Yapıcı, 2004, s. 6). Therefore, it becomes much easier to identify vocabulary level from the age of 5 . Frequency lists obtained through written or oral data in vocabulary determination studies have an important place in mother language teaching. Aksan (2000) states that the first 1000 words that are used most frequently in a language meet approximately $80 \%$ of the lingual productions and reveals the representation power of the first 1000 words in the frequency lists. Corpus studies, which are much more voluminous than frequency lists, are also important in language teaching. Creating corpus-based frequency lists at every level is important in terms of functional use in vocabulary teaching. The corpus-based frequency list created for a language represents the general view of the language. Comparison of such a list and frequency lists prepared for special purposes shows 
the commonality and dissimilarity between the two lists, so that the data obtained is guiding in the language learning and teaching process.

The vocabulary of preschool children aged 60 months and over was determined, a frequency list was obtained, and this list was compared with various corpus-based lists. In this study, carried out to reveal the difference between the frequency lists and the words used by preschool children in the language acquisition process, following questions were sought:

1. How different are the first 1000 words of preschool children and the first 1000 words in Aksan et al.'s (2017) A Frequency Dictionary of Turkish (Turkish Frequency Dictionary) study?

2. How different are the first 1000 words of preschool children and the first 1000 words of the "Target Word List" in Karadag's (2019b) Vocabulary Teaching book?

3. How different are the first 1000 words of preschool children and the first 1000 words of the children books (Baş, 2006)?

4. How different are the first 1000 words of preschool children and the first 1000 words of the $1^{\text {st }}$ grade Turkish textbooks?

5. How different are the first 1000 words of preschool children and the first 1000 words of the primary school students (Karadag, 2005)?

\section{Method}

The case study method, which is one of the qualitative research approaches, was used in the research. According to Creswell (2013: 97), case study research is the researcher's use of multiple sources of information (e.g., observations, interviews, audio-visual) about real life, a current limited system (a situation), or multiple constrained systems (states) in a given time. It is a qualitative approach in which it collects detailed and in-depth information through materials and documents and reports, and introduces a situation description or situation themes. Holistic multiple case design was used here since there are multiple cases in the research and each case has to be analysed with a holistic approach and compared with one another. The case in the study is the comparison of the preschool children's first most frequently used 1000 words and various frequency lists.

\section{Result and Discussion}

The results obtained are as follows:

According to the verbal data obtained through interactive reading, the total number of words used by preschool children is 21,299 while the number of different words is 1732 . The children repeated each different word an average of 12.29 times in their speech. Acarlar (2005) states that as the total number of words used by children increases, word repetitions also increase. Nouns were used mostly used in the speeches. These nouns are related to the concepts that the child is most associated with in his daily life and the concepts in his/her rich imagination worlds. According to their developmental level, they use all word types easily because they internalize the grammar rules in this period. It has been determined that the children use the first 100 most frequently used words richly in terms of their types, as they establish cause-effect, purpose-effect relationships while speaking, and they can establish relationships between events and characters, and make inquiries with their increasing curiosity.

Comparing the first 1000 words of preschool children with the first 1000 words in Aksan et al.'s (2017) study called A Frequency Dictionary of Turkish, it was found that the two lists were compatible at a rate of $25.4 \%$ but differed by $74.6 \%$. Since FDT is a corpus that reveals the general aspects of the language and contains a lot of abstract words, which is contrary to the developmental characteristics of children (Karadag, 2019), it is normal that the rate of agreement between the two lists is low.

When the first 1000 words of preschool children and the first 1000 words in the "Target Word List", which is the frequency list created by Karadag (2018) from the written expressions of the students at the basic education level, were compared, it was found that the two lists were compatible with $53.6 \%$ and differed by $46.4 \%$. 
When the first 1000 words of preschool children were compared with the first 1000 words in children's books, it was determined that the two lists were compatible at a rate of $47.5 \%$ and different at a rate of $52.5 \%$. Comparing the frequency list of primary school students with the frequency list of children's books, Baş (2006) found that the two lists were compatible at a rate of $63 \%$. It is seen that the ratio of common words between children and books in both studies is low.

A $37.8 \%$ of commonality and $62.2 \%$ of differentiation were found between the first 1000 words of preschool children and the first 1000 words in the $1^{\text {st }}$ grade Turkish textbook. The difference between the language of the children in the acquisition period and the languages of the books is acceptable, but the fact that this difference in textbooks is higher than that of children books is quite striking.

The first 1000 words of preschool children and the first 1000 words of primary school students were found to be compatible with $45.5 \%$ and different by $54.5 \%$ when compared.

According to the comparison results of the lists, it is seen that the compatibility rate between the first 1000 words of the children and the Turkish Frequency Dictionary, and the $1^{\text {st }}$ Grade Turkish Book is quite low while this rate between the first 1000 words of the children, the Target Word List, children's books, and the first 1000 words of the primary school students is rather higher when the developmental level of the children in the language acquisition process is taken into account.

According to the results of this study, the fact that the first 1000 words of preschool children and the first 1000 words of other corpus do not overlap more than half shows that these corpus used in the study cannot be used as a reference for preschool children. For this, it is revealed that functional and large corpuses to be prepared through the oral languages of preschool children should be used as a reference in mother tongue education with more comprehensive studies. This result coincides with the study of Karadağ (2019a) which reveals that there is a need for a large volume of special children's language collection in terms of teaching Turkish as a mother tongue. In addition, since language and mental development is rapid in the pre-school period and the number of stimuli increases day by day, the corpus that will be prepared should be updated at regular intervals. 